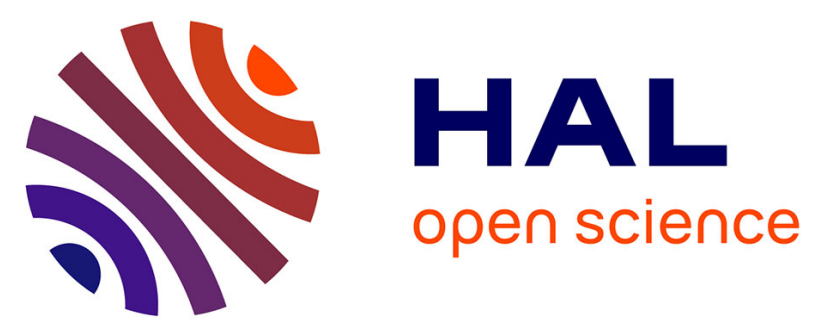

\title{
Chronostratigraphy of the Baringo-Tugen Hills-Barsemoi (HSPDP-BTB13-1A) core - 40Ar/39Ar dating, magnetostratigraphy, tephrostratigraphy, sequence stratigraphy and Bayesian age modeling
}

A. L. Deino, Mark J. Sier, Dominique I Garello, C. Brenhin Keller, John Kingston, Jennifer Scott, Guillaume Dupont-Nivet, Andrew. Cohen

\section{To cite this version:}

A. L. Deino, Mark J. Sier, Dominique I Garello, C. Brenhin Keller, John Kingston, et al.. Chronostratigraphy of the Baringo-Tugen Hills-Barsemoi (HSPDP-BTB13-1A) core - 40Ar/39Ar dating, magnetostratigraphy, tephrostratigraphy, sequence stratigraphy and Bayesian age modeling. Palaeogeography, Palaeoclimatology, Palaeoecology, 2021, 570, pp.109519. 10.1016/j.palaeo.2019.109519 . insu02403903

\section{HAL Id: insu-02403903 \\ https://hal-insu.archives-ouvertes.fr/insu-02403903}

Submitted on 11 Dec 2019

HAL is a multi-disciplinary open access archive for the deposit and dissemination of scientific research documents, whether they are published or not. The documents may come from teaching and research institutions in France or abroad, or from public or private research centers.
L'archive ouverte pluridisciplinaire HAL, est destinée au dépôt et à la diffusion de documents scientifiques de niveau recherche, publiés ou non, émanant des établissements d'enseignement et de recherche français ou étrangers, des laboratoires publics ou privés. 


\section{Journal Pre-proof}

Chronostratigraphy of the Baringo-Tugen Hills-Barsemoi (HSPDP-BTB13-1A) core - 40Ar/39Ar dating, magnetostratigraphy, tephrostratigraphy, sequence stratigraphy and Bayesian age modeling

Alan L. Deino, Mark J. Sier, Dominique I. Garello, C. Brenhin Keller, John D. Kingston, Jennifer J. Scott, Guillaume DupontNivet, Andrew S. Cohen

PII: $\quad$ S0031-0182(19)31084-3

DOI: $\quad$ https://doi.org/10.1016/j.palaeo.2019.109519

Reference: $\quad$ PALAEO 109519

To appear in: Palaeogeography, Palaeoclimatology, Palaeoecology

Please cite this article as: A.L. Deino, M.J. Sier, D.I. Garello, et al., Chronostratigraphy of the Baringo-Tugen Hills-Barsemoi (HSPDP-BTB13-1A) core - 40Ar/39Ar dating, magnetostratigraphy, tephrostratigraphy, sequence stratigraphy and Bayesian age modeling, Palaeogeography, Palaeoclimatology, Palaeoecology (2019), https://doi.org/ 10.1016/j.palaeo.2019.109519

This is a PDF file of an article that has undergone enhancements after acceptance, such as the addition of a cover page and metadata, and formatting for readability, but it is not yet the definitive version of record. This version will undergo additional copyediting, typesetting and review before it is published in its final form, but we are providing this version to give early visibility of the article. Please note that, during the production process, errors may be discovered which could affect the content, and all legal disclaimers that apply to the journal pertain.

(C) 2019 Published by Elsevier. 
Chronostratigraphy of the Baringo-Tugen Hills-Barsemoi (HSPDP-BTB13-1A) core $-{ }^{40} \mathrm{Ar} /{ }^{39} \mathrm{Ar}$ dating, magnetostratigraphy, tephrostratigraphy, sequence stratigraphy and Bayesian age modeling

\author{
Alan L. Deino ${ }^{1}$, Mark J. Sier ${ }^{2,3}$, Dominique I. Garello ${ }^{4}$, C. Brenhin Keller ${ }^{1}$, John D. \\ Kingston ${ }^{5}$, Jennifer J. Scott ${ }^{6}$, Guillaume Dupont-Nivet ${ }^{7,8}$, Andrew S. Cohen ${ }^{9}$ \\ ${ }^{1}$ Berkeley Geochronology Center, 2455 Ridge Rd., Berkeley, CA 94709 USA; \\ adeino@bgc.org (corresponding author) \\ ${ }^{2}$ Department of Earth Sciences, University of Oxford, South Parks Road, OX1 3AN \\ Oxford, United Kingdom \\ ${ }^{3}$ CENIEH, Paseo Sierra de Atapuerca 3, 09002 Burgos, Spain \\ ${ }^{4}$ School of Earth and Space Exploration, Arizona State University, Tempe, AZ 85287, \\ USA \\ ${ }^{5}$ Department of Anthropology, University of Michigan, Ann Arbor, MI 48109, USA \\ ${ }^{6}$ Department of Earth and Environmental Sciences, Mount Royal University, Calgary, \\ Alberta T3E 6K6, Canada \\ 7Univ Rennes, CNRS, Géosciences Rennes - UMR 6118, F-35000 Rennes, France. \\ ${ }^{8}$ Institute for Earth and Environmental Science, Potsdam University, Potsdam, \\ Germany. \\ ${ }^{9}$ Department of Geosciences, University of Arizona, Tucson, AZ 85721, USA
}

\begin{abstract}
The Baringo-Tugen Hills-Barsemoi 2013 drillcore (BTB13), acquired as part of the Hominin Sites and Paleolakes Drilling Project, recovered $228 \mathrm{~m}$ of fluviolacustrine sedimentary rocks and tuffs spanning a $\sim 3.29-2.56 \mathrm{Ma}$ interval of the highly fossiliferous and hominin-bearing Chemeron Formation, Tugen Hills, Kenya. Here we present a Bayesian stratigraphic age model for the core employing chronostratigraphic control points derived from ${ }^{40} \mathrm{Ar} /{ }^{39} \mathrm{Ar}$ dating of tuffs from core and outcrop, ${ }^{40} \mathrm{Ar} /{ }^{39} \mathrm{Ar}$ age calibration of related outcrop diatomaceous units, and core magnetostratigraphy. The age model reveals three main intervals with distinct sediment accumulation rates: an early rapid phase from 3.2-2.9 Ma; a relatively slow phase from 2.9-2.7 Ma; and the highest rate of accumulation from 2.7-2.6 Ma. The intervals of rapid accumulation correspond to periods of high Earth orbital eccentricity, whereas the slow accumulation interval corresponds to low eccentricity at 2.9-2.7 Ma, suggesting that astronomically mediated climate processes may be responsible for the observed changes in sediment accumulation rate. Lacustrine transgression-regression events, as delineated using sequence stratigraphy, dominantly operate on precession scale, particularly within the high eccentricity periods. A set of erosively based fluvial conglomerates correspond to the 2.9-2.7 Ma interval, which could be related to either the depositional response to low eccentricity or to the development of unconformities due to local tectonic activity. Age calibration of core magnetic susceptibility and gamma density logs
\end{abstract}


indicates a close temporal correspondence between a shift from high- to lowfrequency signal variability at $\sim 3 \mathrm{Ma}$, approximately coincident the end of the midPiacenzian Warm Period, and the beginning of the cooling of world climate leading to the initiation of Northern Hemispheric glaciation c. 2.7 Ma. BTB13 and the Baringo Basin records may thus provide evidence of a connection between highlatitude glaciation and equatorial terrestrial climate toward the end of the Pliocene.

\section{Keywords}

Chemeron Formation; Pliocene; eccentricity; precession; paleoclimate; paleolimnology.

\section{Introduction}

The Hominin Sites and Paleolakes Drilling Project (HSPDP) was initiated to develop a broader understanding of the influence of climate change on the process of human evolution. The guiding concept behind the project is that in order to obtain the most complete, detailed, and reliable paleoclimatic constraints on evolutionary processes, not only is it necessary to study the outcrops where hominin fossils are found, but it is also essential to acquire deep drillcores from nearby paleolake sedimentary strata that potentially provide a more complete and unaltered record than discontinuous surface exposures. Lake-bed drillcores provide the opportunity to collect continuous, high resolution, quantitative proxy records of key paleoclimatic (temperature, precipitation, seasonality), ecology (watershed vegetation, fire history, lake ecology) and landscape/tectonic variables critical for evaluating competing hypotheses linking environmental history to human evolution.

Six Plio-Pleistocene paleolake sites in Kenya and Ethiopia were chosen for this project based on their proximity to important hominin fossil sites, and on the time interval they encompass, in order to document the environmental context of human evolution through key intervals of our evolutionary history (Campisano et al., 2017; Cohen et al., 2016). One of these critical intervals is the Plio-Pleistocene transition, a time of both important Earth history events (i.e., the onset of global cooling and Northern Hemisphere glaciation) and events in hominin prehistory (evolutionary change and extinction of Australopithecus afarensis (Lockwood et al., 2000; Reed and Rector, 2007), first appearance of our own genus Homo (Villmoare et al., 2015), and the earliest record of stone tools (Harmand et al., 2015) and cutmarks (McPherron et al., 2010).

The Baringo-Tugen Hills-Barsemoi core site (the core has the project identifier 'HSPDP-BTB13-1A,' herein abbreviated 'BTB13') was chosen by HSPDP as a unique opportunity to investigate these transitions in eastern Africa (Figure 1). The cored strata target the highly fossiliferous Plio-Pleistocene Chemeron Formation, exposed in the axial portion of the central Kenya Rift, east of the southern margin of Lake Baringo. The specific targeted interval begins at the top of a previously documented sequence of five precessionally paced lake expansion events from 2.7-2.55 Ma (Deino et al., 2006; Kingston et al., 2007). Based on outcrop 
mapping, the core interval was anticipated to extend downward through nonlacustrine intervals, with possible return to alternating lacustrine conditions at $\sim 3$ Ma toward the base of the core. The upper Cenozoic strata of this region have been explored paleontologically for decades (Bishop et al., 1971; Hill, 1985; Hill et al., 1985; Hill, 1994; Hill and Ward, 1988), and have yielded important hominin finds, including Orrorin tugenensis (Senut et al., 2001), Ardipithecus? (Hill, 1985; White et al., 2009), and early Homo (Hill et al., 1992). The large-scale climatic fluctuations exhibited by the Chemeron Formation during the latest Pliocene to earliest Pleistocene, combined with close proximity to a rich record of hominin evolution, ideally situates BTB13 to explore and develop hypotheses of climatic influences on hominin evolution that are central to the HSPDP project goals.

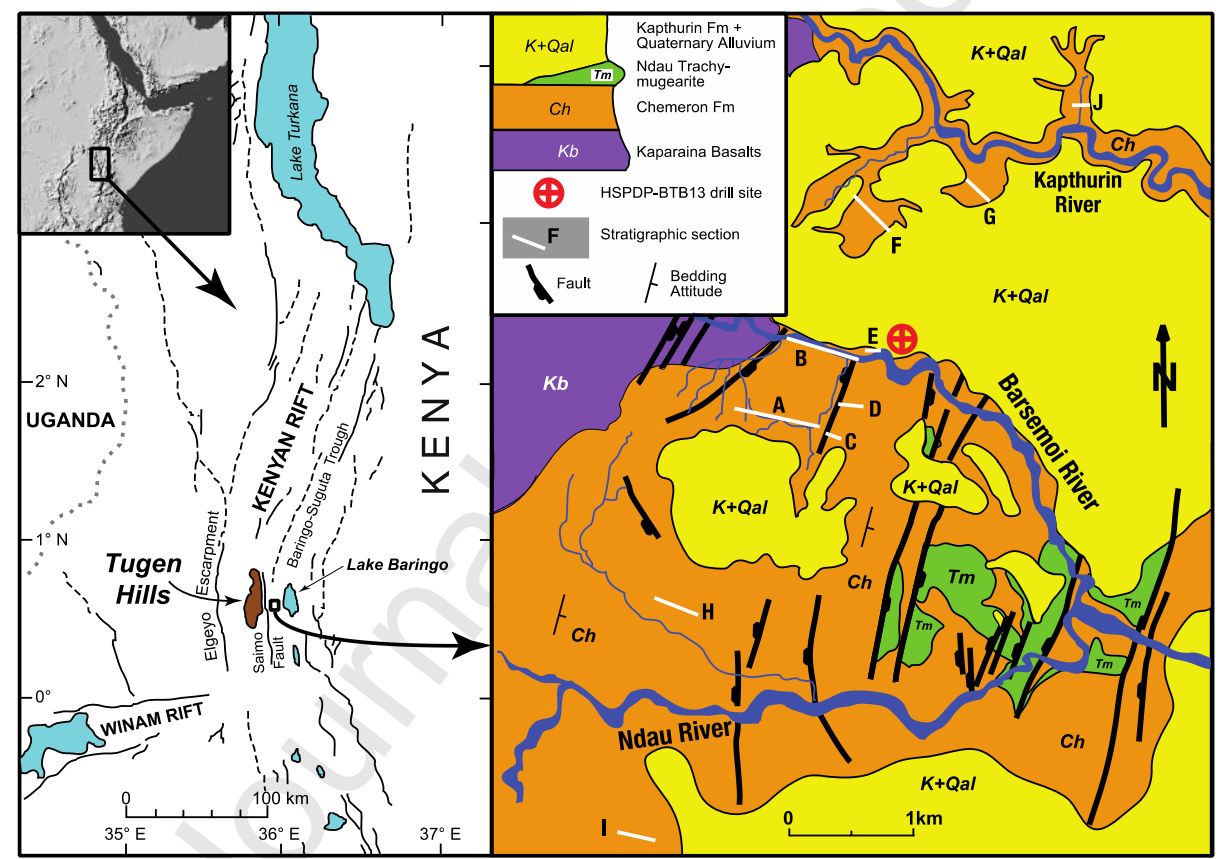

Figure 1. Location map and geological setting of BTB13. Stratigraphic sections are described elsewhere (Deino et al., 2006; Kingston et al., 2007).

\section{Geological setting}

The BTB13 drill site is situated near the axis of the Kenya Rift, in east-central Kenya. Exposures of probable rift-related volcanic activity extend back as far as 21 Ma along the boundary faults of the rift in this region (Chapman and Brook, 1978). Widespread volcanic activity began $\sim 16 \mathrm{Ma}$, and as much as $3000 \mathrm{~m}$ of lava flows, pyroclastic rocks, and intercalated fluviolacustrine beds accumulated intermittently 
into the late Pleistocene, terminating with the fluvial deposits and volcaniclastic tuffs of the Kapthurin Formation (Chapman et al., 1978). The exact structural position of the drill site is unusual in the East African Rift System overall, in that it lies in the eastern foothills of a major intra-rift westward tilting horst that forms the Tugen Hills. The Saimo Fault, which bounds the Tugen Hills on the east, has a maximum displacement of $4000 \mathrm{~m}$ (Chapman et al., 1978), and is situated only 10 $\mathrm{km}$ west of the drill site. The age of movement along the fault is not precisely known, but has been interpreted to mostly post-date deposition of the Chemeron Fm. (Chapman et al., 1978). Structural deformation in post-Chemeron Fm. time has resulted in extensive normal faulting of the eastern foothills of the Tugen Hills encompassing the drill site area.

The Chemeron Fm. spans approximately 3.7 Ma, from 5.3-1.6 Ma (McCall et al., 1967; Chapman and Brook, 1978; Hill et al., 1986; Deino et al., 2002; Deino and Hill, 2002; Deino et al., 2006; Kingston et al., 2007), and is composed of subaerial fluvial/alluvial and lacustrine sedimentary strata and siliceous tuffs. The formation is exposed discontinuously in the foothills east of the Tugen Hills and west of Lake Baringo (Figure 1). Chemeron Fm. strata typically rest disconformably on the widespread Kaparaina Basalts ( 5.7-5.3 Ma; Chapman and Brook, 1978; Hill et al., 1986; Deino et al., 2002), and in the eastern exposures are overlain with angular unconformity by the middle Pleistocene Kapthurin Formation (Deino and McBrearty, 2002; Blegen, 2017). Present day exposures of the Chemeron Fm. occur in two roughly $\mathrm{N}-\mathrm{S}$ discontinuous patches: (1) a southeastern belt between the Kapthurin and Chemeron rivers (encompassing the location of BTB13) - the 'Chemeron basin,' and (2) a belt 11-25 km to the northwest extending from Kipcherere, northward through Tabarin and beyond (the 'Kipcherere/Tabarin basin'). Previously it was believed that the Kipcherere/Tabarin basin predated the Chemeron basin by several million years, however recent and ongoing field investigations reveal that both areas extend to $\sim 5 \mathrm{Ma}$. Exposed strata younger than $\sim 3 \mathrm{Ma}$ are restricted to the Chemeron basin.

Between $0^{\circ} 30^{\prime} \mathrm{N}$ and $0^{\circ} 35^{\prime} \mathrm{N}$ in the Chemeron basin near the drill site, the Chemeron Fm. is preserved within an eastward-dipping structural block frequently cut by $\sim \mathrm{N}-\mathrm{S}$ normal faults. The Ndau, Barsemoi and Kapthurin rivers and their tributaries expose these strata primarily in east-west major drainages and variably oriented tributary channels to these major rivers. The lithologies exposed are mainly fluviolacustrine beds composed of mudstone, siltstone, and sandstone with intercalations of tuff, diatomaceous sediments, and conglomerate.

Within an area of approximately 5-6 km N-S of the drill site, the Chemeron Fm. from 2.7-2.55 Ma is characterized by a distinctive lithologic package of five 2-7 $\mathrm{m}$ thick diatomaceous beds, intercalated with fluvial and alluvial fan coarse-grained clastic deposits and tuffs (the oldest of the lacustrine beds is locally represented by a tuffaceous mudstone). Based on the precessionally paced timing of these diatomaceous/fluvial cycles, and their correspondence to an interval of extreme solar-insolation fluctuations at a maximum of earth orbital eccentricity, the succession is interpreted to reflect a narrow interval of orbitally forced wet/dry climatic conditions leading to the abrupt appearance of deep lacustrine 
paleoenvironments within the axial portion of the rift (Deino et al., 2006; Kingston et al., 2007).

BTB13 was drilled just north of the main Barsemoi River drainage in June, 2013 (location $0.55458^{\circ} \mathrm{N}, 35.93748^{\circ} \mathrm{E}$ ). The location was selected with the intention of sampling the 2.7-2.55 Ma diatomaceous/subaerial cycles toward the top, and downward through strata potentially as old as 4-5 Ma. Technical problems ultimately prevented drilling to depths greater than $228 \mathrm{~m}$. In general, the core is dominated by coarse-grained clastic deposits ranging from muddy fine-grained sandstones to pebble-conglomerates, intercalated with clayey and diatomaceous lacustrine deposits (Westover, this issue; Scott, this issue), and can be subdivided into four main lithologic intervals: (1) a conglomerate- and mudstone-dominated interval at the base ( 228 mbs- 201 mbs); (2) a finer-grained clastic-dominated interval with relatively deep lacustrine deposits occasionally present $(\sim 201 \mathrm{mbs}-$ $\sim 107 \mathrm{mbs}$ ); (3) a second interval with abundant conglomerates ( 107 mbs $-\sim 78$ mbs); and, (4) an upper interval with diatomaceous and clayey deep lacustrine sediments intercalated with fine-grained clastic sediments $(\sim 78 \mathrm{mbs}$ to the top of the core at $5 \mathrm{mbs}$ ).

An accurate chronostratigraphic representation of the core, both in terms of absolute age and realistic age uncertainties, is critical for understanding the rates of processes interpreted from the core itself, and for precisely relating core lithostratigraphic events and paleoenvironmental proxies to broader regional and global scale events. We establish four types of chronostratigraphic age control: (1) new ${ }^{40} \mathrm{Ar} /{ }^{39} \mathrm{Ar}$ single-crystal K-feldspar dates on tuffs from core samples; (2) new ${ }^{40} \mathrm{Ar} /{ }^{39} \mathrm{Ar}$ dating of tuffs correlated to BTB13 by geochemical analyses of outcrop samples; (3) correlation to the core of a distinctive succession of thick diatomaceous units whose ages are calibrated through outcrop ${ }^{40} \mathrm{Ar} /{ }^{39} \mathrm{Ar}$ dating and paleomagnetism (Deino et al., 2006; Kingston et al., 2007), and (4) new paleomagnetic reversal stratigraphy from core samples. We then employ Bayesian methods to develop a chronostratigraphic model of BTB13, using the established age control.

\section{Methods}

\section{1. ${ }^{40} \mathrm{Ar} /{ }^{39} \mathrm{Ar}$ dating}

Tuffaceous zones in BTB13 were identified by visual inspection of both the working and archival core halves, examined immediately after core splitting during the Initial Core Description (ICD) sampling phase at the National Lacustrine Core Facility (LacCore) in December 2013. Initial inspection was completed promptly (within minutes to hours of core splitting), to facilitate observation of subtle lithologic variations indicating tephra characteristics and contacts, before later alteration of the surfaces due to drying and oxidation, and to obtain samples for dating prior to other sampling procedures. Possible tuffaceous zones were further examined during the ICD using smear slides and, where identification of shard texture was difficult, by desktop scanning electron microscope (Hitachi TM-1000). Follow-up acquisition of high-resolution core images helped identify further 
potential tuffaceous horizons, and to provide a stratigraphic context for relevant beds. In total, 56 samples were taken from the working core halves for further processing at the Berkeley Geochronology Center (BGC).

Initial mineral separations were designed to retain all material and employed only distilled water, since follow-up studies such as tephra geochemistry require unaltered material from residual material for analysis. Separations began with gentle disaggregation and wet sieving through a new 90 or 400 micron sieve bag, depending on grain size. K-feldspar in the coarser grained fraction was concentrated with a Frantz magnetic separator (if necessary), hand-picked, washed in 5\% HF and distilled water, and hand-picked again to obtain the clearest, most inclusion-free material. Typically, it was unnecessary to use heavy liquids to separate plagioclase from K-feldspar, as most tephra have only anorthoclase as the feldspar component.

The completed separates for ${ }^{40} \mathrm{Ar} /{ }^{39} \mathrm{Ar}$ dating were irradiated in the Cd-lined CLICIT position of the Oregon State University TRIGA reactor in five batches (BGC irradiation numbers 432 for 2.5 hours, 437 for 2.63 hours, 441 for 7 hours, 449 for 3 hours, and 461 for 4 hours). One irradiation (449) employed sanidine from the Fish Canyon Tuff of Colorado as a monitor mineral (orbitally referenced age of $28.201 \pm$ $0.0231 \sigma$ Ma (Kuiper et al., 2008), whereas all others used sanidine phenocrysts from the Alder Creek Rhyolite of California (orbitally referenced age $=1.1848 \pm$ 0.0006 Ma (Niespolo et al., 2017). Reactor-induced isotopic production ratios for these irradiations were: $\left({ }^{36} \mathrm{Ar} /{ }^{37} \mathrm{Ar}\right)_{\mathrm{Ca}}=2.65 \pm 0.02 \times 10^{-4},\left({ }^{38} \mathrm{Ar} /{ }^{37} \mathrm{Ar}\right)_{\mathrm{Ca}}=1.96 \pm 0.08$ $\times 10^{-5},\left({ }^{39} \mathrm{Ar} /{ }^{37} \mathrm{Ar}\right) \mathrm{Ca}=6.95 \pm 0.09 \times 10^{-4},\left({ }^{37} \mathrm{Ar} /{ }^{39} \mathrm{Ar}\right)_{\mathrm{K}}=2.24 \pm 0.16 \times 10^{-4}$, $\left({ }^{38} \mathrm{Ar} /{ }^{39} \mathrm{Ar}\right)_{\mathrm{K}}=1.220 \pm 0.003 \times 10^{-2},\left({ }^{40} \mathrm{Ar} /{ }^{39} \mathrm{Ar}\right)_{\mathrm{K}}=2.5 \pm 0.9 \times 10^{-4}$. Atmospheric ${ }^{40} \mathrm{Ar} /{ }^{36} \mathrm{Ar}=298.56 \pm 0.31$ (Lee et al., 2006) and decay constants follow (Min et al., 2000). Previously published ${ }^{40} \mathrm{Ar} /{ }^{39} \mathrm{Ar}$ ages referenced herein (Deino et al., 2006) are recalculated for consistency using the decay constants and Fish Canyon sanidine age stated above.

Following a period of at least several weeks of radiological 'cooling' after irradiation, the feldspars were analyzed individually by the ${ }^{40} \mathrm{Ar} /{ }^{39} \mathrm{Ar}$ technique using single-crystal incremental heating ( $\mathrm{SCIH})$. In the SCIH technique, individual phenocrysts are incrementally heated in 3-10 steps (depending on grain size and gas yield) at progressively increasing power to fusion, to better examine the argon systematics of an individual grain (consistency of release patterns in terms of age, radiogenic content, and chemical composition), more effectively drive off surficial and trapped atmospheric contamination, and maintain fairly consistent gas yields for improved spectrometer detection reproducibility. These detailed analyses were conducted on a Nu Instruments Noblesse noble-gas mass spectrometer, featuring a high-efficiency ionization source and simultaneous multi-isotope measurement using all ion-counting electron multiplier detection systems.

Although incremental heating is a time-consuming process, potentially resulting in analysis of fewer grains than a single-step (total-fusion) approach, the step-heating experiments yield information about the argon systematics of individual crystals that permit testing for geological reliability. Here, we examine the incremental release experiment for calculated age consistency as a function of the fraction of ${ }^{39} \mathrm{Ar}$ released. Grains that have a near-uniform release pattern ('apparent age plateau') are deemed more geologically reliable than those with 
irregular age patterns. The plateau identification algorithm used here (following Fleck et al., 1977), delineates the set of contiguous steps encompassing the greatest percent of ${ }^{39} \mathrm{Ar}$ release that exhibit an acceptable MSWD ('mean square of weighted deviates,' with a threshold probability $>95 \%$ that the observed scatter is caused by analytical error alone and that geological scatter is not demonstrated). A plateau must comprise at least $50 \%$ of the total ${ }^{39} \mathrm{Ar}$ release and consist of at least three consecutive steps. The age and uncertainty assigned to the plateau are weighted means (weighted by the inverse variance of each step) and modified standard error (standard error expanded by root MSWD if MSWD >1). After single-grain plateau determination, but before computing overall means, individual sample data sets were aggregated by tuff unit (bed as delineated in the core lithostratigraphy) where multiple samples for an individual tuff were processed, for improved statistical power in subsequent data treatment (Table 1).

Table 1. BTB13 tephra units

\begin{tabular}{|c|c|c|c|}
\hline $\begin{array}{l}\text { Tuff } \\
\text { Unit }\end{array}$ & $\begin{array}{c}\text { Top } \\
\text { (mbs) }\end{array}$ & $\begin{array}{c}\text { Bottom } \\
\text { (mbs) }\end{array}$ & $\begin{array}{l}\text { Core Sample } \\
\text { (BTB13-1A-) }\end{array}$ \\
\hline 1-05-2/1* & 17.39 & 17.49 & $05 Q-259-61$ \\
\hline $1-10-2 / 1^{*}$ & 29.39 & 29.42 & $10 Y-20-2$ \\
\hline $1-17-2 / 1$ & 48.17 & 48.18 & $17 Q-228-30$ \\
\hline $1-21-1 / 1$ & 59.61 & 59.64 & $21 Q-1126-128$ \\
\hline $1-26-2 / 1^{*}$ & 76.20 & 76.28 & 26Q-2 114-118 \\
\hline $1-26-3 / 1^{*}$ & 76.61 & 76.68 & 26Q-3 12-14 \\
\hline $1-31-1 / 1$ & 86.80 & 86.83 & 31Q-1 97-99 \\
\hline $1-31-3 / 1$ & 88.67 & 88.74 & $31 Q-32-7$ \\
\hline $1-32-1 / 1^{*}$ & 89.34 & 90.15 & $\begin{array}{l}32 Q-1110-119 \\
32 Q-147-61 \\
\end{array}$ \\
\hline $1-32-2 / 1$ & 91.62 & 91.65 & $32 Q-2$ 128-131 \\
\hline $1-34-2 / 1$ & 96.62 & 97.03 & $\begin{array}{l}34 Q-2 \text { 67-72 } \\
34 Q-2 \text { 89-94 }\end{array}$ \\
\hline $1-35-3 / 1^{*}$ & 100.90 & 101.10 & $\begin{array}{l}35 Q-36-8 \\
35 Q-38-14 \\
35 Q-3 \quad 16-19 \\
\end{array}$ \\
\hline $1-36-1 / 1^{*}$ & 101.15 & 101.40 & $36 Q-1$ 19-32 \\
\hline $1-36-1 / 2$ & 101.71 & 101.76 & 36Q-1 64-69 \\
\hline $1-39-1 / 1$ & 110.92 & 111.13 & 39Q-1 89-92 \\
\hline $1-42-2 / 1$ & 120.45 & 120.51 & $\begin{array}{l}42 Q-22-6 \\
42 Q-28-10\end{array}$ \\
\hline $1-46-2 / 1$ & 132.72 & 132.86 & $46 Q-231-36$ \\
\hline $1-56-1 / 1^{*}$ & 159.37 & 159.40 & $\begin{array}{l}56 Q-135-40 \\
56 Q-1 \quad 40-44\end{array}$ \\
\hline $1-61-2 / 1$ & 176.14 & 176.30 & 61Q-2 58-62 \\
\hline $1-64-1 / 1^{*}$ & 183.99 & 184.26 & $\begin{array}{l}64 Q-164-71 \\
64 Q-171-79\end{array}$ \\
\hline $1-64-2 / 1^{*}$ & 185.97 & 186.02 & 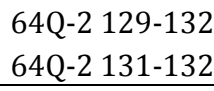 \\
\hline $1-65-2 / 1$ & 187.87 & 188.01 & $65 Q-23-10$ \\
\hline $1-68-2 / 1^{+}$ & 196.58 & 196.59 & $68 Q-256-59$ \\
\hline
\end{tabular}




\begin{tabular}{|llll|}
\hline $1-68-2 / 2$ & 196.69 & 196.74 & $68 Q-269-74$ \\
\hline $1-68-2 / 3$ & 197.00 & 197.01 & $68 Q-2101-102$ \\
\hline $1-68-3 / 1^{*+}$ & 197.03 & 197.37 & $\begin{array}{l}68 Q-30-8 \\
68 Q-38-20\end{array}$ \\
\hline $1-70-1 / 1^{*+}$ & 201.86 & 202.45 & $\begin{array}{l}70 Q-120-22 \\
70 Q-150-60 \\
70 Q-160-64\end{array}$ \\
\hline $1-75-1 / 1^{\dagger}$ & 211.48 & 212.11 & $\begin{array}{l}75 Q-133-36 \\
75 Q-139-46\end{array}$ \\
\hline $1-79-2 / 1^{\dagger}$ & 221.67 & 221.97 & $79 Q-240-51$ \\
\hline $1-79-3 / 1$ & 222.52 & 222.58 & $79 Q-35-6$ \\
& & & \\
\hline
\end{tabular}

*Included in age model.

†Tuffaceous sandstone

At this stage, the geochronological data consist of a suite of plateau ages derived from analysis of single phenocrysts, perhaps from multiple samples but aggregated on a per-tuff basis obtained for each tuff bed. Computation of an eruptive age from a suite of single-grain ages is often complicated by the occurrence of anomalous results, from sources including xenocrysts, excess ${ }^{40} \mathrm{Ar}$ trapped in primary phenocrysts, or subtle alteration. Statistical treatments, described below, are taken to mitigate their influence of anomalous ages on the determination of an eruption age.

A similar situation arises from efforts to date the lowest, coarse-grained detrital part of the core where primary tuffs were not available (below 197 mbs). Several samples of tuffaceous (fine pumice-bearing) coarse-grained sandstone or pebbly conglomerate were dated with the goal of identifying a reasonable eruption age for the primary tuffaceous component. In these cases, the interval between eruption and deposition is not necessarily geologically rapid. Nevertheless the goal of data synthesis is this case is similar to that of a primary tuff: to derive the youngest valid age component to represent the closest approximation of the depositional age of the stratigraphic unit.

A three-stage outlier detection scheme was applied on a unit-by-unit basis to help isolate a potential primary age component. First, distinctly older xenocrysts were excluded from the age population based on a procedure that evaluates age gaps in the ordered age distribution. This algorithm proceeds by testing each analysis against all younger analyses. A gap score is generated by evaluating the magnitude of the age difference for each pair of analyses, divided by their joint error combined in quadrature. If this score exceeds a fixed, pre-established criterion, the older analysis, and all analyses older than it, are deemed outliers and excluded from the age population. An arbitrary criterion for forming this decision (gap score = 7) effectively identifies age gaps obvious to a human observer, but has minimal effect on distributions that lack a visually pronounced modal gap. In two cases (units 1-61$2 / 1$ and 1-79-2/1), an older mode was not recognized by the gap algorithm, and was eliminated manually. Secondly, outliers were omitted based on their deviation from the median ('normalized median absolute deviation' $=2$ ). Only those units with a remaining population count $n \geq 4$ were considered adequate for further processing 
(13 out of the original 27 tuffaceous stratigraphic units). An additional sample (134-2/1) was eliminated because of a marginal number of scattered analyses $(n=4)$ with more than double the relative mean age uncertainty of the other tuff units.

Finally, because of the high number of anomalous older ages prevalent in many of the samples, we utilize here a relatively novel approach to identifying a depositional age based on Bayesian estimation (Keller et al., 2018). This method offers an objective technique formulated with minimal pre-conditions, which can be applied universally to the current data set, and to other problematic suites of ${ }^{40} \mathrm{Ar} /{ }^{39} \mathrm{Ar}$ ages. First, a minimally trimmed age data set for each unit was established using a gap elimination procedure described above (gap $=20$ ). Using this filtered data set, depositional ages were calculated using a Bayesian parameter estimation approach that takes advantage of the ability to construct an informative prior estimate of the relative closure age distribution, the form of which is a characteristic of the physical processes responsible for the heterogeneity of Ar-Ar closure ages in a given tephra horizon. In particular, we know a priori that although inherited, xenocrystic, or detrital grains may predate deposition, no ${ }^{40} \mathrm{Ar} /{ }^{39} \mathrm{Ar}$ ages may postdate deposition, except due to analytical uncertainty. Consequently, we expect a relative distribution of true single-crystal closure ages that is sharply truncated at the time of deposition. Empirically, we observe that this distribution tends to take a roughly triangular form, with a greater number of ages clustered around the youngest single age. Considering both our requirement for a sharp truncation at deposition and the form of the observed (bootstrapped) distribution, we find that a simple triangular distribution effectively encapsulates our prior expectation for the relative distribution of individual crystal ages in a given sample. Since the deposition age acts as a parameter (the minimum) of our closure age distribution (formally an array of hyperparameters), we use a likelihood-based approach to estimate the value and uncertainty of this parameter and thus the depositional age for each sample.

\subsection{Tephrochemical correlation}

Glass shards and feldspars of BTB13 core tephra were analyzed for major, minor, and trace elements using EMPA and LA-ICP-MS at Arizona State University and the Carnegie Institute of Washington, respectively, for the purposes of identifying core-to-outcrop correlations (Garello et al., this issue; Garello, 2019). We use glass shard over feldspar fingerprinting as the predominant data for establishing correlations. Glass shard chemical analysis is a widely used method and has been proven to be an accurate way to assess tephra correlation (Kuehn et al., 2011; Lane et al., 2011; Lane et al., 2013; Lowe, 2011; Pearce et al., 2012). Feldspar phenocrysts are analyzed for geochemical correlations where glass shards are absent in targeted BTB core tephra. Due to the generally wide range in compositions within a tephra and indistinct feldspar populations in this study, tephra age, stratigraphic positioning, and glass shard analyses, when applicable, are used as primary correlative determinants. Correlations based solely on feldspar are considered tentative. 


\subsection{Age calibration of core diatomaceous beds}

We previously documented the occurrence of a 2.68-2.58 Ma, precessionally paced succession of five 3-7 m thick, laterally persistent white diatomaceous beds intercalated in the fluviolacustrine sedimentary succession of the middle Chemeron Fm. in the Barsemoi River area (numbered for reference from oldest to youngest 'Diatomite 1' or 'D1,' through 'Diatomite 5' 'D5') (Deino et al., 2006; Kingston et al., 2007). Field investigations in 2018 demonstrated that the lowest of these beds (D1) is expressed as a diatomaceous lacustrine mudstone near to the core site, and as diatomite elsewhere. These five lacustrine units are exposed just hundreds of meters north of the plateau on which the BTB13 drill site is situated, approximately along strike of the general bedding attitude, and so it was anticipated that this succession would also be identified in the upper part of the core. Four prominent diatomites and a relatively deep-water clayey lacustrine bed were observed in the upper part of BTB13, ranging in thickness from 2 to $7 \mathrm{~m}$, and roughly equally spaced stratigraphically from $8.6 \mathrm{mbs}$ to $52.8 \mathrm{mbs}$. Correlation of the second diatomite from the top in the core is supported by the identification of a geochemically linked ash bed near the top of D4 in outcrop, as described above. Previous studies of the diatomite-dominates succession in the Barsemoi River drainage established the abrupt nature of the upper and lower contacts of the diatomaceous lacustrine facies (Deino et al., 2006; Kingston et al., 2007). These lithostatic boundaries are considered to provide approximate time-lines from section to section in outcrop, and into the core.

(Deino et al., 2006) employed the longest, most complete measured section near the Barsemoi River as a reference section for understanding detailed chronostratigraphic relationships (Section A-A'). Eight tuff units were dated by the single-crystal total-fusion ('SCTF') ${ }^{40} \mathrm{Ar} /{ }^{39} \mathrm{Ar}$ technique: three above the diatomaceous sequence; three above/within/and below D4; and two below the entire succession. These ages encompass a stratigraphic interval $178 \mathrm{~m}$ thick and range from 2.922 to $2.390 \mathrm{Ma}$. Interpolated ages for the upper and lower contacts of diatomaceous horizons were calculated assuming linear sedimentation rates between the dated tuffs that bracket the interval.

Two modifications to the data and approach in (Deino et al., 2006) were utilized here to provide more accurate correspondence to the current analysis. All ${ }^{40} \mathrm{Ar} /{ }^{39} \mathrm{Ar}$ ages have been recalculated for consistency with the decay constants and standard ages used herein. Also, rather than use step-wise line segments between dated tuffs in the stratigraphic succession (Deino et al., 2006), we have applied the same Bayesian stratigraphic analysis to these legacy data as used for BTB13 chronostratigraphy (methods described in 3.5). The control points $\left({ }^{40} \mathrm{Ar} /{ }^{39} \mathrm{Ar}\right.$ ages and depths in section A, Deino et al., 2006) are provided in Table S3.

\subsection{Paleomagnetism methods}

The following is a summary of the magnetostratigraphic analytical technique applied to BTB13 (Sier et al., this issue). Magnetostratigraphy relies on identifying 
paleomagnetic directions of either normal polarity with declination towards the north and positive downward inclinations or reversed polarities with declination towards the south and negative downward inclinations (inclinations are opposite in the southern hemisphere). Due to the rotational movement of the core during the coring process, the azimuthal orientation of the recovered core segments has been lost. Generally, normal or reversed magnetic polarities can still be recovered by positive or negative paleomagnetic inclination respectively. However, this method cannot be employed at low equatorial latitudes such as the BTB13 site $\left(0^{\circ} 33^{\prime} \mathrm{N}\right.$ latitude), due to near zero paleomagnetic inclinations. Two methods are used to overcome this difficulty (Sier et al., 2017). The first reorients the core segments with respect to the azimuth of the bedding dip direction (assumed constant) preserved in the sedimentary fabric and expressed in the anisotropy of the magnetic susceptibility (AMS). This method requires there be a significant difference $\left(>10^{\circ}\right)$ between the coring dip and the perpendicular of the bedding dip. The second method takes advantage of the presence of secondary viscous remanent magnetization oriented in the present day field, thus providing a reference for reorientating core segments (Sier et al., 2017; Sier et al., this issue).

A total of 567 paleomagnetic samples were taken at 543 levels of BTB13 resulting in an average spatial resolution of $0.41 \mathrm{~cm}$. A first set of 100 samples throughout the core were carefully demagnetized to identify Characteristic Remanent Magnetization (ChRM) and the possible stratigraphic locations of paleomagnetic reversals. Further sample analyses were conducted in the intervals of possible magnetic reversals to achieve the highest degree of resolution possible with the available sample set. From the original 567 samples, 262 were sufficient to identify the reversals. These samples were fully thermally demagnetized to $600^{\circ} \mathrm{C}$ in either 12 or 14 temperature steps using an ASC thermal demagnetizer with a residual field lower than $20 \mathrm{nT}$. After each temperature step the remaining Natural Remanent Magnetization (NRM) was measured with a 2G DC-SQUID cryogenic magnetometer. Paleomagnetism.org, an online multi-platform open source environment for paleomagnetic data analysis, was used to interpret the demagnetization results and identify the ChRM directions (Koymans et al., 2016).

\subsection{Bayesian stratigraphic age modeling}

The primary goal of this study is to produce a continuous age-depth model for BTB13 using all available constraints - including the core depositional ages obtained from the ${ }^{40} \mathrm{Ar} /{ }^{39} \mathrm{Ar}$ age spectra by the first MCMC inversion, tephrocorrelation, diatomaceous beds and tuff ages correlated from outcrop, and paleomagnetic reversal ages. Finally, control points with exaggerated uncertainties are added at the top and bottom of the core to better constrain the trend of the model extrapolation. All BTB13 chronostratigraphic control points are then together used to constrain the final core age-depth model.

In order to obtain a consistent age-depth model that accurately incorporates all available age constraints, we again use a Bayesian method based on the Metropolis algorithm. The algorithm requires us to calculate the likelihood of obtaining the observed data from a given model, adjust the proposed model, and 
accept that proposal with a calculated probability. We calculate the model for equally spaced points $(20 \mathrm{~cm})$ throughout the depth of the core. This age model is directly constrained in two ways: (1) it must be monotonically non-decreasing with depth; and (2) the likelihood of the observed data corresponding to a proposed given model is readily calculated given the uncertainty of each data point and its absolute deviation from the proposed model age at the same depth. In this way, only the model point closest in depth to a given observed age is directly constrained by that observed age, but each model point is indirectly constrained by every data point through our constraint of superposition.

As before, the proposed model is perturbed by a symmetric Gaussian proposal distribution, changing only one model parameter at a time (i.e., the age at a single depth). However, after this perturbation, adjacent model points may be moved in time as necessary to preserve superposition: any points adjacent to our perturbed point that would violate superposition are immediately adjusted to have an age equal to the proposed age for our perturbed point, thus maintaining a monotonically non-decreasing model with depth. Consequently, although the model may appear underdetermined given that the number of parameters (number of model age-depth points) generally far exceeds the number of data, the constraint of superposition introduces a strong covariance structure to the model that effectively decreases the number of model degrees of freedom. The set of all accepted proposals provides our age model mean and uncertainty.

\section{Results}

Table 2 shows the final set of chronostratigraphic data supporting a Bayesian age model of BTB13, consisting of five data types: (1) ${ }^{40} \mathrm{Ar} /{ }^{39} \mathrm{Ar}$ ages obtained directly from core samples; (2) ${ }^{40} \mathrm{Ar} /{ }^{39} \mathrm{Ar}$ ages of outcrop tuffs correlated into BTB13; (3) diatomaceous bed top and bottom ages calibrated in outcrop, and correlated into the core; (4) paleomagnetic reversal boundaries; and (5) points derived from linear extrapolation of sediment accumulation rates to the top and bottom of the core. Each of these data types is discussed below.

Table 2. Age model chronostratigraphic data set

\begin{tabular}{|c|c|c|c|c|c|}
\hline Datum Event & $\begin{array}{l}\text { Age } \\
\text { (Ma) }\end{array}$ & $\begin{array}{c} \pm 1 \sigma \text { Age } \\
\text { (Ma) }\end{array}$ & \% Error & $\begin{array}{c}\text { Core Depth } \\
\text { (mbs) }\end{array}$ & $\begin{array}{c}\text { Thickness } \\
\text { (m) }\end{array}$ \\
\hline \multicolumn{6}{|c|}{${ }^{40} \mathrm{Ar} /{ }^{39} \mathrm{Ar}$ dated core tephra grouped by stratigraphic unit } \\
\hline $1-05-2 / 1$ & 2.587 & 0.006 & $0.2 \%$ & 17.45 & 0.11 \\
\hline $1-10-2 / 1$ & 2.598 & 0.087 & $3.3 \%$ & 29.40 & 0.02 \\
\hline $1-26-2 / 1$ & 2.709 & 0.007 & $0.3 \%$ & 76.24 & 0.09 \\
\hline $1-26-3 / 1$ & 2.736 & 0.018 & $0.7 \%$ & 76.62 & 0.07 \\
\hline $1-32-1 / 1$ & 2.812 & 0.014 & $0.5 \%$ & 89.42 & 0.14 \\
\hline $1-35-3 / 1$ & 2.929 & 0.005 & $0.2 \%$ & 101.00 & 0.18 \\
\hline $1-36-1 / 1$ & 2.910 & 0.006 & $0.2 \%$ & 101.33 & 0.27 \\
\hline $1-56-1 / 1$ & 3.089 & 0.026 & $0.8 \%$ & 159.37 & 0.09 \\
\hline
\end{tabular}




\begin{tabular}{|c|c|c|c|c|c|}
\hline |1-64-1/1 & 3.178 & 0.033 & $1.0 \%$ & 184.00 & 0.15 \\
\hline $1-64-2 / 1$ & 3.184 & 0.010 & $0.3 \%$ & 186.00 & 0.03 \\
\hline $1-68-3 / 1$ & 3.215 & 0.007 & $0.2 \%$ & 197.14 & 0.20 \\
\hline $1-70-1 / 1$ & 3.208 & 0.036 & $1.1 \%$ & 202.21 & 1.08 \\
\hline \multicolumn{6}{|c|}{${ }^{40} \mathrm{Ar} /{ }^{39} \mathrm{Ar}$ dated outcrop tuffs correlated into core } \\
\hline Unit B (BARS97-6) & 2.604 & 0.005 & $0.2 \%$ & 17.45 & 0.11 \\
\hline Unit H (upper; BARS/94-3) & 2.732 & 0.007 & $0.3 \%$ & 76.24 & 0.07 \\
\hline Unit H (lower; BARS/94-7; BARS/94-9c) & 2.738 & 0.007 & $0.3 \%$ & 76.62 & 0.07 \\
\hline Unit J (BARS94-2) & 2.922 & 0.012 & $0.4 \%$ & 101.16 & 0.46 \\
\hline \multicolumn{6}{|l|}{ Diatomite top/bottom contacts } \\
\hline D5 top & 2.580 & 0.007 & $0.3 \%$ & 8.64 & 0.01 \\
\hline D5 bottom & 2.588 & 0.007 & $0.3 \%$ & 10.87 & 0.11 \\
\hline D4 top & 2.603 & 0.003 & $0.1 \%$ & 15.21 & 0.01 \\
\hline D4 bottom & 2.610 & 0.003 & $0.1 \%$ & 22.34 & 0.01 \\
\hline D3 top & 2.622 & 0.007 & $0.3 \%$ & 25.27 & 0.01 \\
\hline D3 bottom & 2.635 & 0.009 & $0.3 \%$ & 32.42 & 0.01 \\
\hline D2 top & 2.654 & 0.010 & $0.4 \%$ & 41.43 & 0.01 \\
\hline D2 bottom & 2.661 & 0.011 & $0.4 \%$ & 43.48 & 0.01 \\
\hline D1 top & 2.677 & 0.011 & $0.4 \%$ & 50.33 & 0.01 \\
\hline D1 bottom & 2.685 & 0.011 & $0.4 \%$ & 52.77 & 0.01 \\
\hline \multicolumn{6}{|l|}{ Paleomagnetic reversal boundaries } \\
\hline Matuyama/Gauss & 2.602 & 0.013 & $0.5 \%$ & 19.79 & 0.20 \\
\hline Upper Kaena & 3.032 & 0.015 & $0.5 \%$ & 125.86 & 0.60 \\
\hline Lower Kaena & 3.116 & 0.015 & $0.5 \%$ & 154.64 & 0.29 \\
\hline Upper Mammoth & 3.207 & 0.015 & $0.5 \%$ & 199.63 & 0.49 \\
\hline \multicolumn{6}{|c|}{ Sediment accumulatioin rate extrapolations at top and bottom of core } \\
\hline Top extrapolated from upper $\sim 75 \mathrm{~m}$ & 2.56 & 0.2 & $7.8 \%$ & 0.00 & 1.00 \\
\hline Bottom extrapolated from lower $\sim 100 \mathrm{~m}$ & 3.28 & 0.2 & $6.1 \%$ & 228.00 & 1.00 \\
\hline
\end{tabular}

\subsection{Chronostratigraphic data from direct ${ }^{40} \mathrm{Ar} /{ }^{39} \mathrm{Ar}$ dating of BTB13 tuffs}

A total of 3,026 SCIH steps on 867 phenocrysts from 43 samples were analyzed (Table S1). 454 of these phenocrysts were rejected as candidates for complete step-heating analysis, after evaluation of one or two low-power steps, due to obviously old xenocrystic ages or high $\mathrm{Ca} / \mathrm{K}$ content (indicative of plagioclase and an anticipated low-precision result), whereas the remainder (413 grains) were carried to completion (example spectra are provided in Figure 2). A dominant proportion of the grains carried to completion in the $\mathrm{SCIH}$ experiments yielded apparent-age plateaus (398 out of 413 grains, Table S2). The apparent-age plateaus are plotted as age-probability density functions in Figure 3, for each stratigraphic unit included in the age model (see Figure SX for probability plots for each tuff unit 
individually). Whereas some units approach simple unimodal Gaussian-like distributions (i.e., unit 1-36-1/1), most exhibit multimodality with ages much older than the inferred stratigraphic age ( 3.4-2.6 Ma upward); these older grains are interpreted as xenocrysts incorporated during eruption, transportation and deposition. Abundant xenocrystic contamination is especially evident in the lower $\sim 25$ meters of the core, where tuffaceous sandstone and gravel units were sampled in an attempt to obtain chronologic control in a zone devoid of primary tuffs. After outlier elimination procedures and Bayesian age estimation as described above, a suite of $12{ }^{40} \mathrm{Ar} /{ }^{39} \mathrm{Ar}$ tuff ages were derived, from $17.45 \mathrm{mbs}$ to $202.21 \mathrm{mbs}$ in the core. The median uncertainty is $0.4 \%$, with a maximum of $3.3 \%$ and minimum of $0.2 \%$.

(A) 26522-01

(B) 26522-02

(C) 26522-03

(D) 26522-04

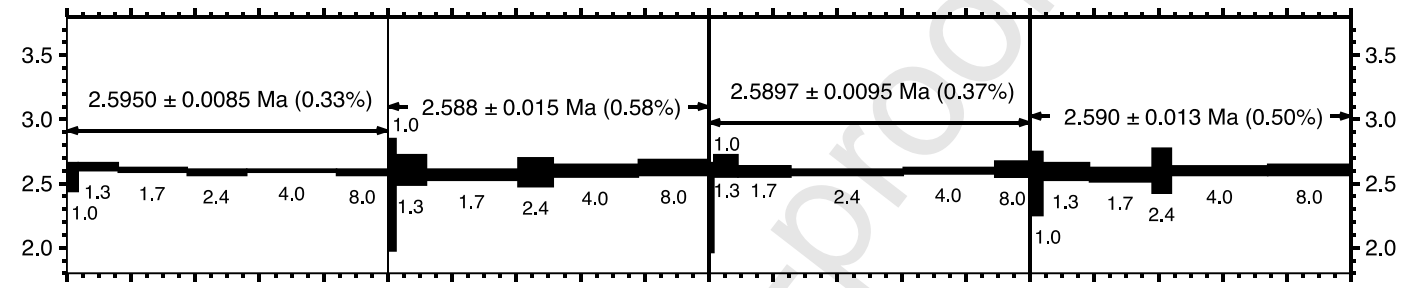

(E) 26522-05

(F) 26522-06

(G) 26522-07

(H) 26522-08

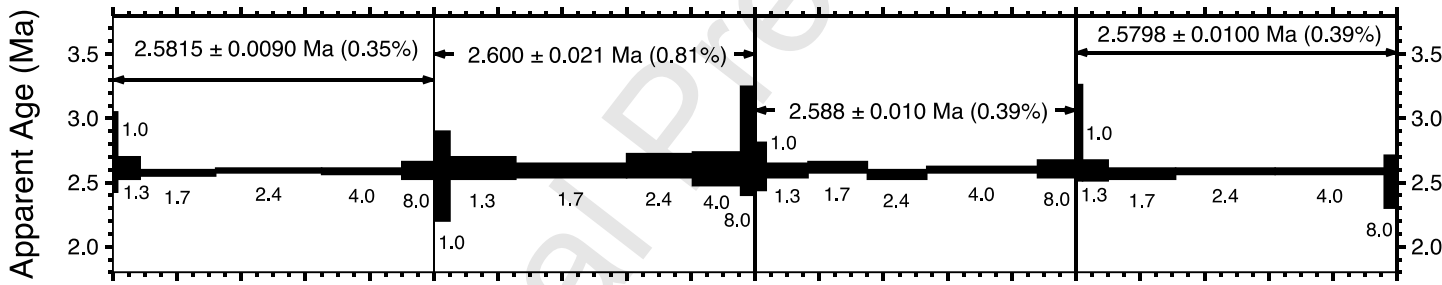

(I) $26522-09$

(J) $26522-10$

(K) 26522-11

(L) $26522-12$

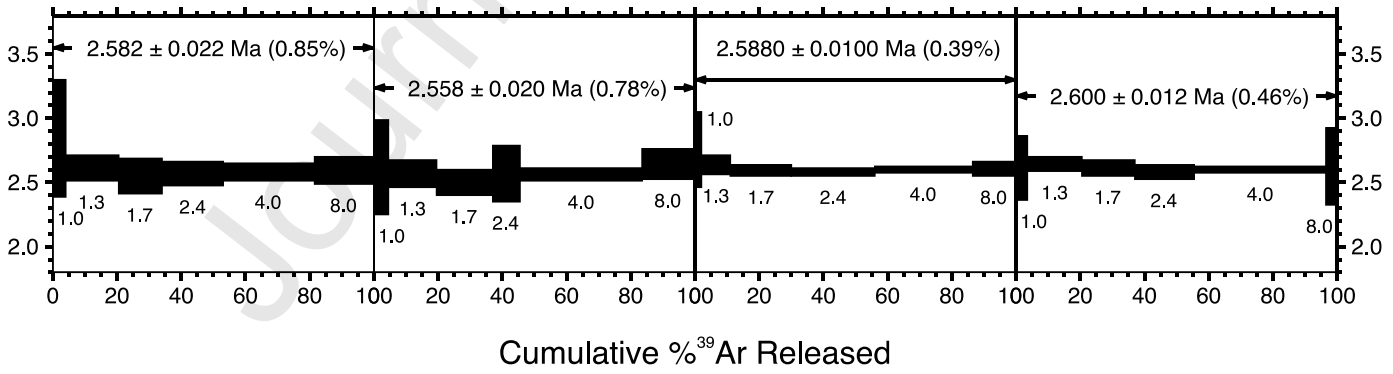

Figure 2. Representative ${ }^{40} \mathrm{Ar} /{ }^{39} \mathrm{Ar}$ incremental heating release spectra for 12 individual K-feldspar grains from stratigraphic unit 1-05/2/1 (full analytical data for all samples are provided in Table S2). Double-barbed arrow indicates the range of heating steps (black boxes) included in the apparent age plateau, with the plateau age given $( \pm 1 \sigma$ uncertainty). Numbers below or to the side of each step give the laser wattage of the gas extraction phase of the analysis. 


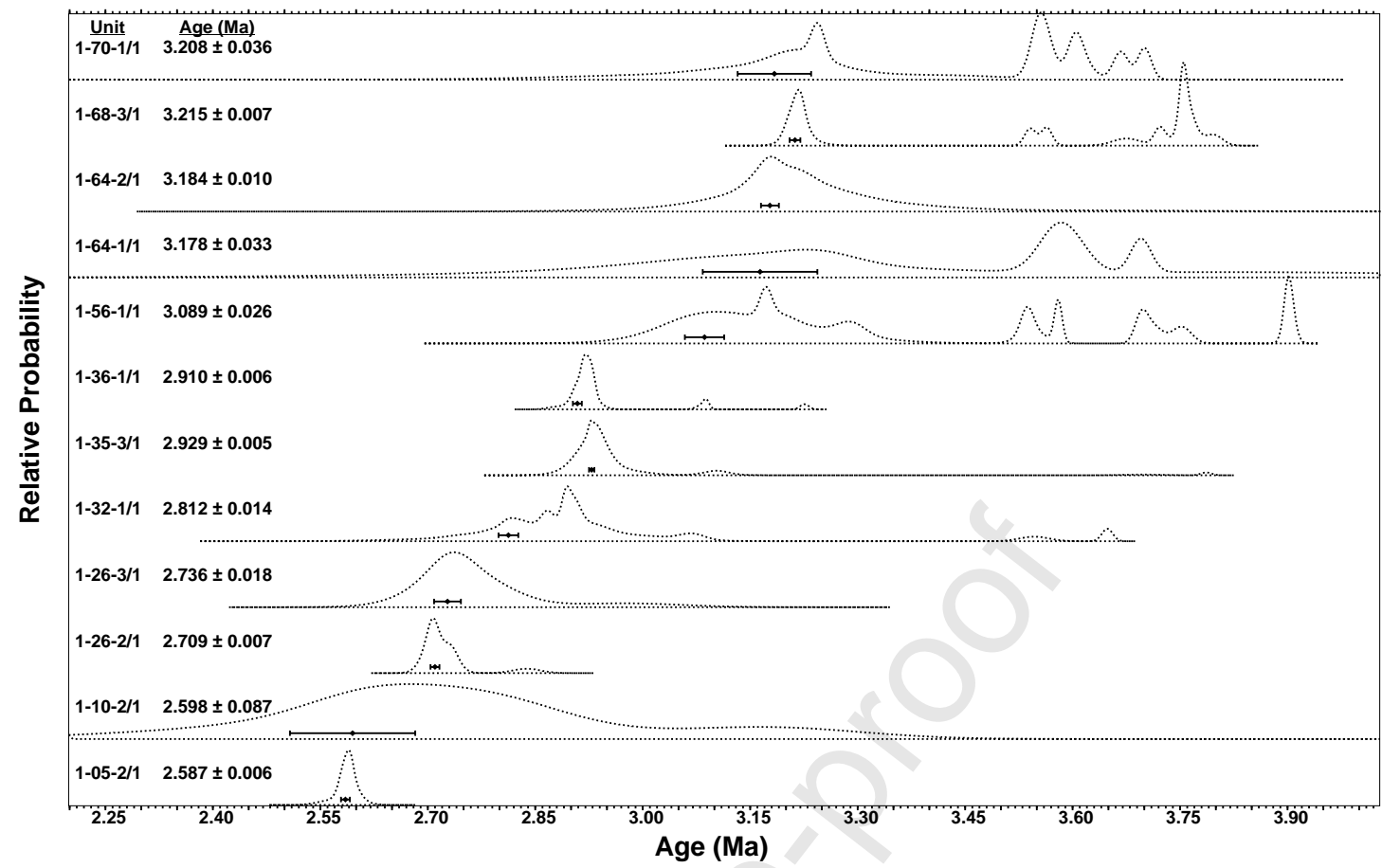

Figure 3. Age-probability density plots of the inferred primary eruptive mode of tuff units included in the age-modeling chronostratigraphy (Table 2). Ages shown as horizontal error bars (with $1 \sigma$ uncertainty) are posterior estimates derived from the Bayesian depositional age modeling described in section 3.5. Dashed line represents age-probability density curve of all step-heating plateaus for a given tuff unit; light grey is the curve after application of the gap outlier algorithm (gap = 20); and the dark grey curve is the Bayesian posterior probability distribution.

\subsection{Chronostratigraphic data from correlation of outcrop-dated tuffs to BTB13}

Detailed discussion of the geochemical correlation effort, using glass and feldspar phenocrysts from tephra deposits, is provided in (Garello et al., this issue; Garello, 2019), and summarized here. ${ }^{40} \mathrm{Ar} /{ }^{39} \mathrm{Ar}$ age control is available for each potential outcrop sample, and preliminary model core ages employing the other chronostratigraphic control data types identify an appropriate time interval for comparison of outcrop-to-core tuff geochemistry.

Although geochemical analysis of glass shards is preferred for our correlation study, glass is preserved in only four BTB13 tephra, all from the upper half of the core (Figure 4; Garello et al., this issue; Garello, 2019), and only one of these could be correlated to outcrop exposures. The uppermost glassy tephra in the core (5Q-2 $(59-61 \mathrm{~cm})$ ) is found $\sim 0.5 \mathrm{~m}$ below the top of Diatomite 4 at $17.45 \mathrm{mbs}$. This sample is a good match chemically for glass from previously dated BARS97-6, from outcrops $0.37 \mathrm{~km}$ to the southwest of the drill site where this tuff occurs within diatomaceous mudstone also at the top of Diatomite 4 (tephra 'Unit B' of 
Deino et al., 2006). Unit B is found across $3 \mathrm{~km}$ within stratigraphic sections $\mathrm{E}, \mathrm{H}$, and I (Figure 1; Deino et al., 2006; Kingston et al., 2007).
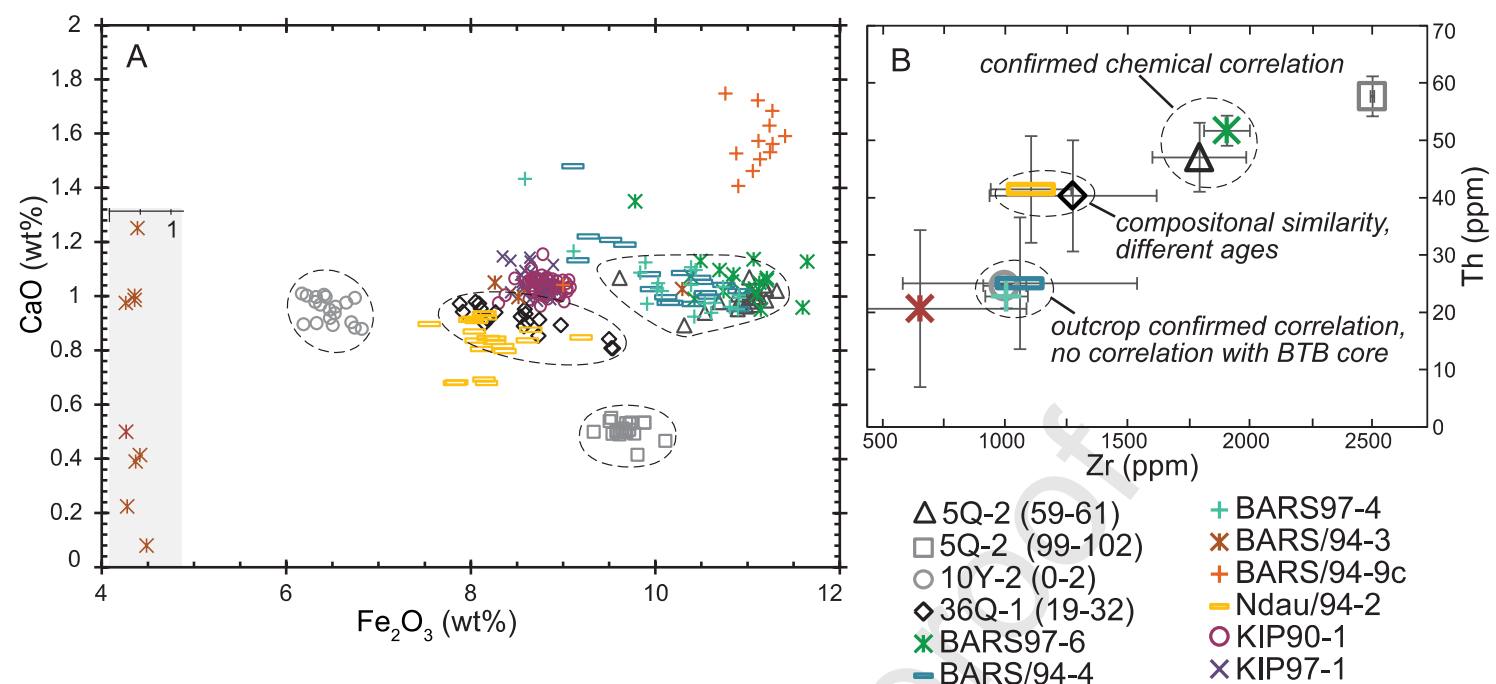

Figure 4. Bivariate compositional plots of glass shard chemistry from BTB13 (grey and black symbols) and Chemeron Fm. outcrop tephra (colored symbols), after Garello, 2019. A) Normalized weight percent $\mathrm{CaO} v s \mathrm{Fe}_{2} \mathrm{O}_{3}$ for individual glass shards. Dashed fields indicate the range of the BTB13 tephra. Grey box highlights BARS94-3 shard compositions at an expanded horizontal scale. B) Th vs $\mathrm{Zr}$ average composition. Dashed fields encircle compositional similar samples. Sample names beginning with numbers refer to BTB13 core segments; names beginning with 'BAR' are from nearby outcrops in the Barsemoi River drainage (Deino et al., 2006); KIP97-1 and KIP90-1 are Chemeron Fm. outcrop samples collected from a tuff at the Kipcherere locality $10.5 \mathrm{~km}$ to the northwest, with an unpublished age ${ }^{40} \mathrm{Ar} /{ }^{39} \mathrm{Ar}$ of $\sim 3.20 \mathrm{Ma}$; and NDAU/94-2 is a tuff from the Chemeron Fm. $2.7 \mathrm{~km}$ southwest of the drill site with an unpublished ${ }^{40} \mathrm{Ar} /{ }^{39} \mathrm{Ar}$ age of $\sim 3.72 \mathrm{Ma}$.

Feldspar phenocryst chemistry in the trachytic assemblage of tephra compositions exhibited by the Chemeron Formation is not as diverse, and often exhibits more within-sample scatter than corresponding volcanic glass. Nevertheless, the geochemical characterization helps to establish three correlations between nearby outcrops to the upper third of BTB13 (Figure 5). Feldspar phenocrysts were separated from 13 core samples and divided into five age groups $(2.54-2.62,2.68-2.75,2.89-2.97,3.11-3.16$, and 3.19-3.23 Ma) as a means of narrowing the potential number of correlative outcrop tuffs (Garello et al., this issue; Garello, 2019). In Age Group 1 (2.54-2.62 Ma), feldspar phenocryst compositional results support the glass shard geochemical correlation between 5Q$2(59-61 \mathrm{~cm})$ with BAR97-6. Age Group $2(2.68-2.75 \mathrm{Ma})$ supports a geochemical link between outcrop tuffs BARS/94-7 and BARS/94-9c with a single thick tephra depositional event represented by two core samples separated by $\sim 40 \mathrm{~cm}: 26 \mathrm{Q}-2$ (114-118 cm) and 26Q-3 (12-14 cm). The two outcrop samples occur in similar 
fault-repeated sections $200 \mathrm{~m}$ apart in the Barsemoi River drainage, and there is a high likelihood they represent the same eruptive event on geochronologic, lithologic, and stratigraphic grounds: these were grouped together as 'Unit $\mathrm{H}^{\text {' of }}$ (Deino et al., 2006). However, the feldspar chemistry, as well as the glass chemistry mentioned above, distinguishes these outcrop samples from BARS/94-3, previously also grouped in Unit $\mathrm{H}$ (Deino et al., 2006). This sample was collected further away (760 $\mathrm{m})$, and the hypothesized equivalence to BARS/94-7 and BARS/94-9c is now shown to be incorrect. In Age Group 3 (2.89-2.97 Ma), outcrop sample BARS/94-2 exhibits good overlap with core tephras 35Q-3 $(16-19 \mathrm{~cm}), 36 \mathrm{Q}-1(19-32 \mathrm{~cm})$, and 36Q-1 $(64-69 \mathrm{~cm})$ in Figure 5. However, in overall elemental comparisons (Garello et al., this issue; Garello, 2019), 36Q-1 (64-69 cm) does not adequately overlap, thus is excluded from correlation. Age Group 4 (3.11-3.16 Ma) feldspar analyses did not result in any identifiable correlations. Within Age Group 5 (3.19-3.23 Ma), a weak correlation is identified between Chemeron Fm. outcrop samples KIP97-1 and KIP90-1 (both collected from the same tuff in an outcrop in the Kipcherere locality $10.5 \mathrm{~km}$ to the northwest, with an unpublished age of $\sim 3.20 \mathrm{Ma}$ ) and core sample $68 \mathrm{Q}-3(8-20 \mathrm{~cm})$. However, the core sample represents pumice fragments in coarsegrained sandstone, present at various levels in this part of the core, thus it is problematic to identify the best level of an emplacement event for primary tephra. Because the correlation is only weakly substantiated, and since the correlative core sample is poorly defined, these outcrop samples are excluded from the BTB13 age model. 

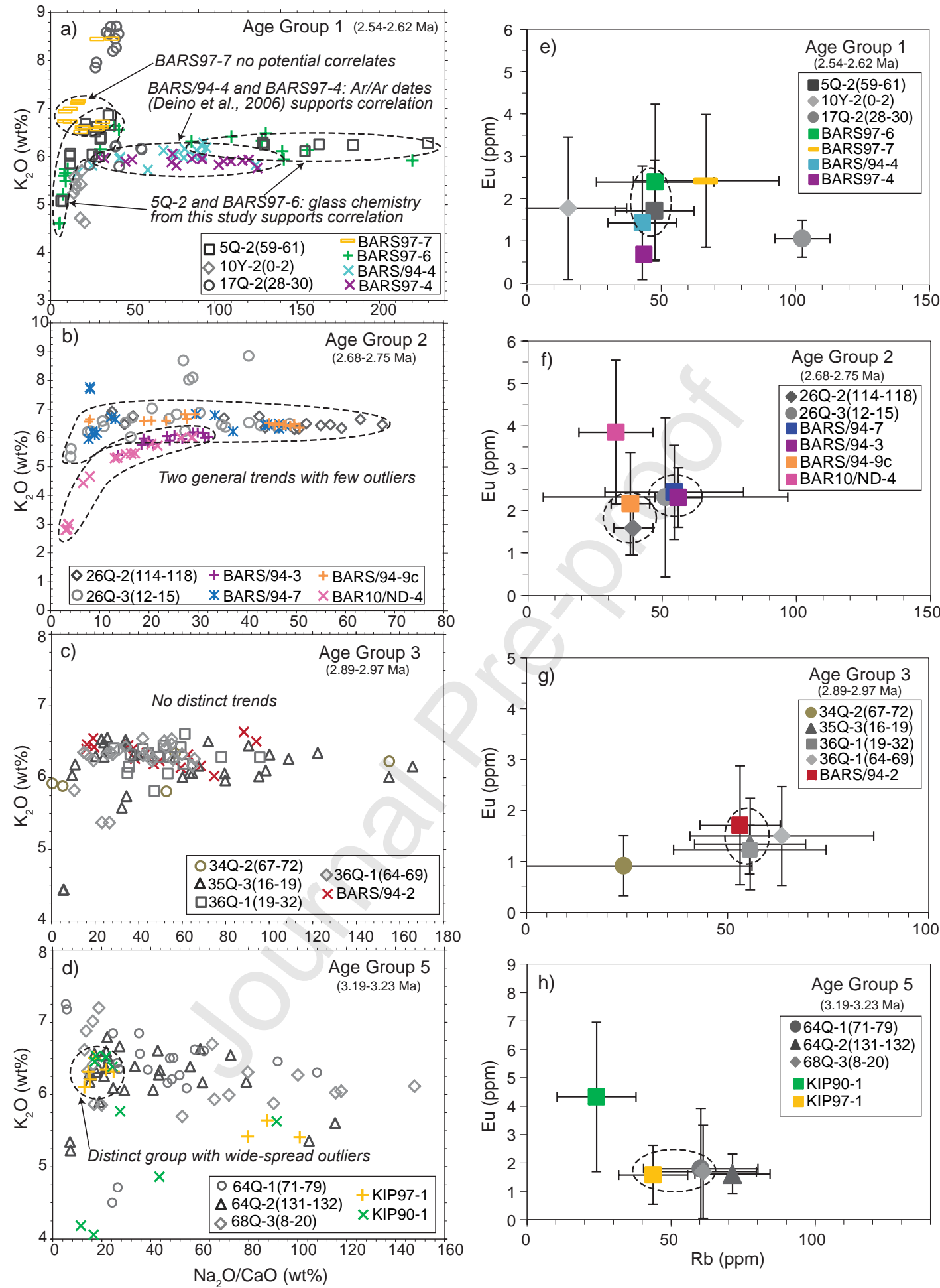

Figure 5. Bivariate compositional plots of feldspar phenocryst chemistry from BTB13 (grey and black symbols) and Chemeron Fm. outcrop tephra (colored symbols), divided into five age groups (after Garello, 2019). Dashed fields delineate compositional similarity and potential correlation. A-D) Normalized $\mathrm{K}_{2} \mathrm{O}$ vs $\mathrm{Na}_{2} \mathrm{O} / \mathrm{CaO}$ of individual crystals. E-H) Eu vs $\mathrm{Rb}$ sample averages, with standard 
deviation bars. Sample names are designated as per Figure 4, with the addition of sample BAR10/ND-4, a tuff from the Chemeron Fm. $2.6 \mathrm{~km}$ southwest of the drill site with an unpublished ${ }^{40} \mathrm{Ar} /{ }^{39} \mathrm{Ar}$ age of $\sim 2.73 \mathrm{Ma}$.

\subsection{Chronostratigraphic data from correlated diatomaceous beds}

The Bayesian stratigraphic model for the outcrop section discussed in 4.6 is provided in Table S4. Resulting interpolated ages for the diatomaceous bed boundaries are listed in Table 2, which include the ages, their uncertainties, and positions of these strata boundaries serving as outcrop age input into the BTB13 age model.

\subsection{Chronostratigraphic data from BTB13 paleomagnetic reversal stratigraphy}

The method of reorienting core segments using bedding dip azimuth identified by AMS could not be used in the case of BTB13 due to variable coring dip and dip directions, and perpendicularity of coring dip to bedding dip through large intervals of the core. Instead, secondary overprints oriented in the present-day field were used to orientating the core paleomagnetic directions (Sier et al., this issue).

Demagnetizations yielded straightforward paths decreasing steadily towards the origin. In most samples, two components are clearly identified, from room temperature to ca. $150-250^{\circ} \mathrm{C}$, and from ca. $175-250^{\circ} \mathrm{C}$ up to $550-600^{\circ} \mathrm{C}$. The hightemperature component, probably carried by titanomagnetite, is interpreted as a primary component acquired shortly after the time of deposition. The lowtemperature component is interpreted as a secondary normal overprint due to its typical orientation either parallel or antiparallel to the high-temperature component. These parallel or antiparallel component configurations were used to identify, respectively, normal or reversed polarity directions of the hightemperature component. By rotating the low-temperature component directions toward the north, and rotating the high-temperature component directions by the same amount, we could determine the original directions of the high-temperature primary magnetizations. These re-orientated high-temperature ChRM directions plotted versus depth define five polarity zones separated by four reversals situated at $19.79 \pm 0.1 \mathrm{mbs}, 125.86 \pm 0.3 \mathrm{mbs}, 154.64 \pm 0.145 \mathrm{mbs}$ and $199.635 \pm 0.245 \mathrm{mbs}$ respectively (Sier et al., this issue). Based on the chronostratigraphic data presented above we have correlated unequivocally the polarity zones from top to bottom for the Matuyama, Gauss, Kaena, and Mammoth chrons.

The paleomagnetic data points use reversal ages provided in the 2012 geomagnetic polarity time scale of (Ogg et al., 2012) ('GPTS12'), with the exception of the Gauss-Matuyama transition. Several alternative ages for this reversal are older than the GPTS12 age of 2.581 Ma. One relevant analysis is that of (Deino et al., 2006) on the age of the reversal as identified and calibrated in D4 of the Barsemoi River drainage, at $2.606 \pm 0.003 \mathrm{Ma}$. (Lisiecki and Raymo, 2005) place the boundary at $2.608 \mathrm{Ma}$ based on a stack of 57 globally distributed marine benthic $\delta^{18} 0$ records. Finally, recent paleomagnetic studies of the Boring volcanic field in the Cascade 
Range, Oregon-Washington, indicate that this transition is older than $2.632 \pm 0.009$ Ma (Hagstrum et al., 2017). In order to maintain independence of the magnetostratigraphic and ${ }^{40} \mathrm{Ar} /{ }^{39} \mathrm{Ar}$ chronostratigraphic control points in the age model, we omit from consideration the (Deino et al., 2006) result for the G/M boundary, but instead choose as a representative value the median of the GPTS12, marine stack, and Boring volcanic field results, or 2.608 Ma.

\subsection{Extrapolated data points at core boundaries}

In order to realistically model the extrapolated upper and lower bounds of the core beyond the limits of the measured constraints (i.e., above $8.64 \mathrm{mbs}$ and below $202.2 \mathrm{mbs}$ ), control points were added based on sediment accumulation rates proximal to the top and bottom of the core (i.e., within $\sim 75 \mathrm{~m}$ of the top and $100 \mathrm{~m}$ of the bottom) - a point at $0 \mathrm{mbs}(2.56 \mathrm{Ma})$, and another at the bottom of the core at $228 \mathrm{mbs}(3.28 \mathrm{Ma})$. Very large uncertainties $( \pm 0.2 \mathrm{Ma})$ were assigned to these points to avoid constraining the model confidence limits in the extrapolated areas.

\subsection{Bayesian age model}

BTB13 extends to $228 \mathrm{mbs}$, with excellent recovery (94.3\%) in all but the uppermost $5 \mathrm{~m}$, where the loss is attributable to disruption from surface regolith processes. Four classes of chronostratigraphic control points have been acquired, encompassing $85 \%$ of the core depth, from $\sim 8.6-202.2$ mbs (Table 2). The Bayesian chronology model presented here is based principally upon these control points, with linear extrapolation of the A-B interval upward, and the $D-G$ interval downward (Figure 6; Table S5). The downward extrapolation, to a maximum of $\sim 3.29 \mathrm{Ma}$ at the base of the core, is consistent with the non-observation of the lower Mammoth paleomagnetic reversal (APTS12 age of $3.330 \mathrm{Ma}$ ) that is expected to lie beneath the maximum core interval recovered. It should be emphasized that the extrapolated portions of the model (0-8.6 mbs and 202.2-228 mbs) are speculative and not as reliable as the $85 \%$ of the model bracketed by chronostratigraphic control points; this is consistent with confidence intervals in these extrapolated areas that increase rapidly with distance from the control points A and G (Figure 6.6). 


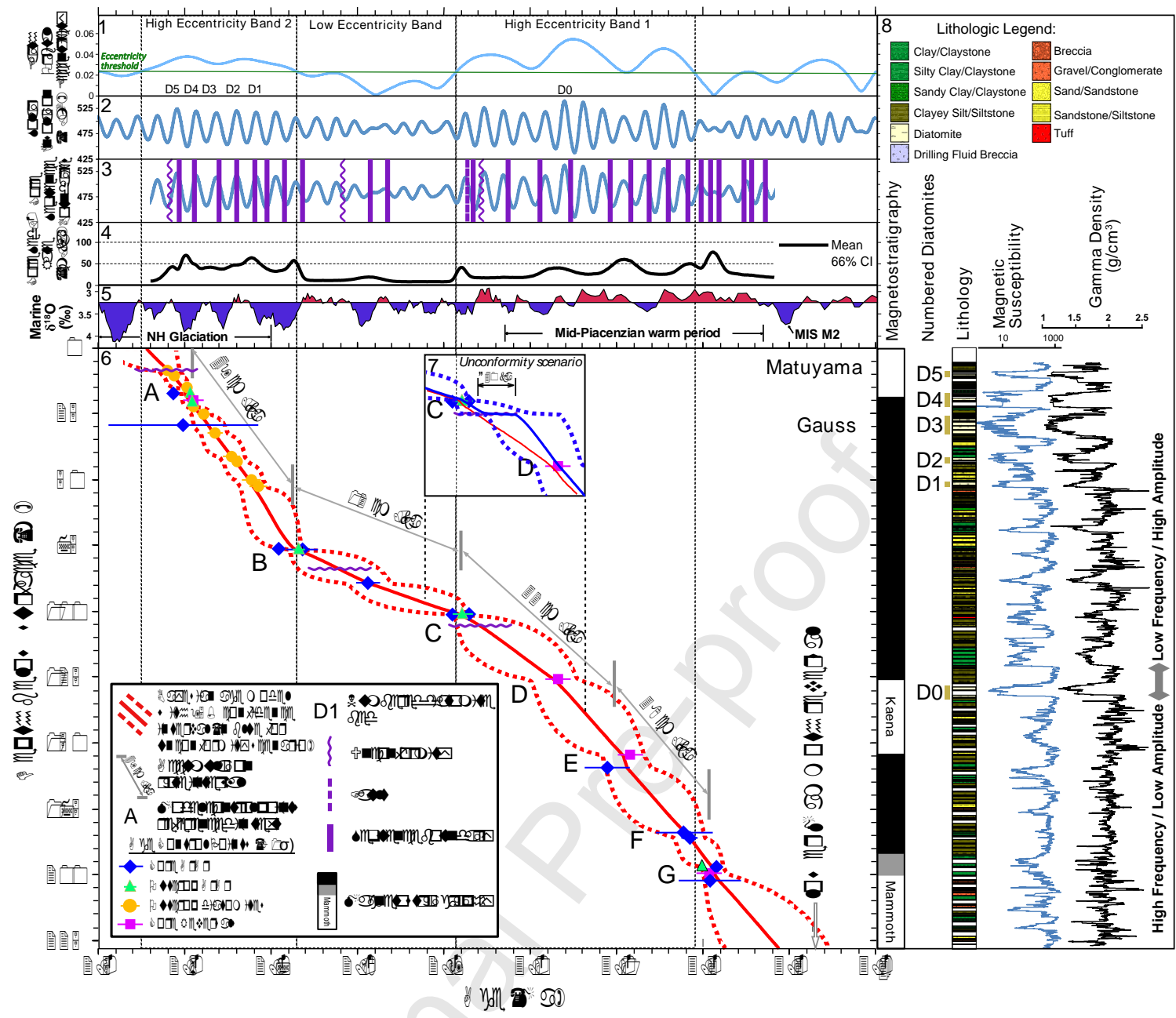

Figure 6. Graph of the BTB13 age model and chronostratigraphic control points, plotted against ancillary data sets. (7.1) Earth orbital eccentricity (Laskar et al., 2004). (7.2) Solar insolation calculated for $30^{\circ} \mathrm{N}$ latitude on June 21 (Laskar et al., 2004). Also shown are the modeled ages of diatomaceous beds D1-D5 observed in the upper part of the core (7.3). Sequence stratigraphic boundaries interpreted from BTB13 (Scott et al., this issue). (7.4) Sediment accumulation rate curve derived from the Bayesian stratigraphic age model at $10 \mathrm{~cm}$ intervals, with estimated $66 \%$ confidence interval. (7.5) LR04 marine benthic $\delta^{18} 0$ stack (Lisiecki and Raymo, 2005) as a proxy for global ice volume. Intervals of high (blue) vs. low (red) ice volume are emphasized at a $\delta^{18} 0$ threshold of 3.75\%. (7.6) BTB13 Bayesian stratigraphic age model (red) with 95\% confidence interval (red dashed area). (7.7) Speculative alternative Bayesian stratigraphic age model (blue solid line), accommodating missing section of $\sim 40 \mathrm{ka}$ duration at the fault identified in the core lithostratigraphy. (7.8) BTB13 magnetostratigraphy, diatomaceous bed location and nomenclature, lithology, magnetic susceptibility, and gamma density measurements, plotted against core depth (mbs). 
The model is particularly well constrained by multiple reinforcing data types at $\sim 20 \mathrm{mbs}(\sim 2.61 \mathrm{Ma}$ or the point marked ' $\mathrm{A}$ ' in Figure 6.6, by core and outcrop ${ }^{40} \mathrm{Ar} /{ }^{39} \mathrm{Ar}$ ages, the location of the Gauss/Matuyama boundary in the core, and ages on diatomaceous bed boundaries), $76 \mathrm{mbs}(\sim 2.72 \mathrm{Ma}$ or ' $\mathrm{B}$ ', by core and outcrop ${ }^{40} \mathrm{Ar} /{ }^{39} \mathrm{Ar}$ ages $), 101 \mathrm{mbs}\left(\sim 2.92 \mathrm{Ma}\right.$ or ' $\mathrm{C}$ ', by core and outcrop ${ }^{40} \mathrm{Ar} /{ }^{39} \mathrm{Ar}$ ages $)$, and $\sim 184-202 \mathrm{mbs}\left(\sim 3.18-3.22 \mathrm{Ma}\right.$ or ' $\mathrm{G}$ ', by core and outcrop ${ }^{40} \mathrm{Ar} /{ }^{39} \mathrm{Ar}$ ages and the location of the upper Mammoth chron boundary). Other than the extrapolations to the top and bottom of the core as noted above, the model is probably most vulnerable to absolute error in age where only paleomagnetic reversals provide constraints, or the core ${ }^{40} \mathrm{Ar} /{ }^{39} \mathrm{Ar}$ ages are relatively imprecise -- between $101 \mathrm{mbs}$ and $184 \mathrm{mbs}$ ( $\mathrm{C}$ and F). It is possible, because of the method used to determine the paleomagnetic reversal stratigraphy, that the core position of the upper Kaena paleomagnetic subchron boundary might be higher than observed, and the lower boundary might be lower, if normal overprints were effective in removing the original reversed magnetic orientation or if no overprints are present. In regards to the lower boundary of the Kaena reversed interval (154.6 mbs, APTS12 age of 3.116 $\mathrm{Ma}$ ), stratigraphic agreement would be improved relative to a fairly imprecise outcrop ${ }^{40} \mathrm{Ar} /{ }^{39} \mathrm{Ar}$ age $(159.4 \mathrm{mbs} ; 3.089 \pm 0.026 \mathrm{Ma}$ ) by placement of the paleomagnetic boundary lower in the core. The Bayesian model takes this stratigraphic age reversal into account by deviating slightly toward the outcrop age, but is dominantly controlled in this interval by the more precise lower Kaena age and position. The model varies smoothly from B-G $(\sim 2.72$ Ma down to $3.22 \mathrm{Ma}$, encompassing the Kaena interval), without major kinks in sediment accumulation rate that might be impetus for re-examination of the model assumptions.

The interval C-D may, alternatively, feature upward continuation of the sediment accumulation rates observed through $D-G$, to a level just below $C$ (Figure 6.7). Two features of the core below $C$ suggest hiatuses: (1) a brecciated fault zone at $103.61 \mathrm{mbs}$; and (2) fluvial incision at $106.69 \mathrm{mbs}$ that appears to remove several meters of sediment. Here, profundal lacustrine deposits are erosionally incised and overlain by conglomerate, and do not follow the predicted succession of facies as seen elsewhere in BTB13, likely representing a significant discontinuity where Walther's Law has been broken. A variant of the reference Bayesian stratigraphic age model was calculated to test the influence of a $\sim 40$ ka hiatus at 106.69 mbs (Table S6). The duration of the hiatus is approximated to maintain steady sediment accumulation rates for the G-C interval. This variant has the principal effect of increasing model ages progressively from near point $\mathrm{D}$ to a maximum of $35 \mathrm{ka}$ just below the hiatus. Almost two full precessional cycles are lost. Although this hiatus model is not adopted as the reference model for BTB13, events within this interval should be considered in light of this potential scenario.

Figure 7 compares several further variations of the Bayesian stratigraphic age model at $50 \mathrm{~cm}$ resolution, using various combinations of the types of chronostratigraphic control points (Table S6). The reference model is provided for comparison with its $95 \%$ confidence interval. A separate model was generated by omitting all core ${ }^{40} \mathrm{Ar} /{ }^{39} \mathrm{Ar}$ age control in order to examine sensitivity to this data type. As shown in Figure 7, the result is almost identical to the reference model, with departures reaching a maximum of $\sim 20$ ka in a limited part of the core at $\sim 80 \mathrm{mbs}$ 
(Point Y, Figure 7). Likewise, a model based only on the core ${ }^{40} \mathrm{Ar} /{ }^{39} \mathrm{Ar}$ ages (green line, Figure 7) follows closely in the upper half of the succession to about $100 \mathrm{mbs}$ both the reference and the model lacking the core ${ }^{40} \mathrm{Ar} /{ }^{39} \mathrm{Ar}$ data set (purple line). However, from $100 \mathrm{mbs}$ to $175 \mathrm{mbs}$ the departure is quite significant (up to $35 \mathrm{ka}$ ) due to the lack of important paleomagnetic reversal control points. Thirdly, Figure 7 illustrates a model based only on core ${ }^{40} \mathrm{Ar} /{ }^{39} \mathrm{Ar}$ control points, but with their age calculated using weighted means of the plateau ages, an alternative approach to the Bayesian technique used above. Although most of the outcrop ${ }^{40} \mathrm{Ar} /{ }^{39} \mathrm{Ar}$ control points are very similar in age and uncertainty, several stratigraphic units exhibit 2.3-3.2\% deviation (Table S7), with the weighted-mean ages being older (points X, $\mathrm{Y}$, and Z, Figure 7). Point X has no influence on either age model due to its high uncertainty, adjacent to much more precise data at 17.45 mbs; however, points $Y$ and $\mathrm{Z}$ are much older in the weighted-mean calculations, and lead to divergence of this model from the reference model or the model without the core ${ }^{40} \mathrm{Ar} /{ }^{39} \mathrm{Ar}$ ages. The Bayesian model ages for the stratigraphic units at $\mathrm{Y}$ and $\mathrm{Z}$ are younger and closer to the other models. Finally, Figure 7 also shows (gold dotted line) a model excluding the diatomaceous age control points. The result differs from the reference model above $75 \mathrm{mbs}$ (where the diatomaceous beds are present) by a nearly constant offset of 7-11 ka toward younger ages, or about half a precessional cycle. Thus, although the relative age spacing of the core diatomaceous beds and sequence boundaries in this interval would not significantly change, these events would no longer align with the peaks of insolation, rather with troughs (Figure 6). Additionally, the confidence interval on the model without the diatomaceous bed control points expands significantly from $0-75 \mathrm{mbs}$ due to the removal of much of the constraining data. The above experiments demonstrate that, while no single chronostratigraphic control type is required to define the general shape and uncertainty of the age model, each type exerts a controlling influence in certain depth ranges. The reference model, incorporating all data types, is taken as the best representation of the age-depth profile of BTB13. 


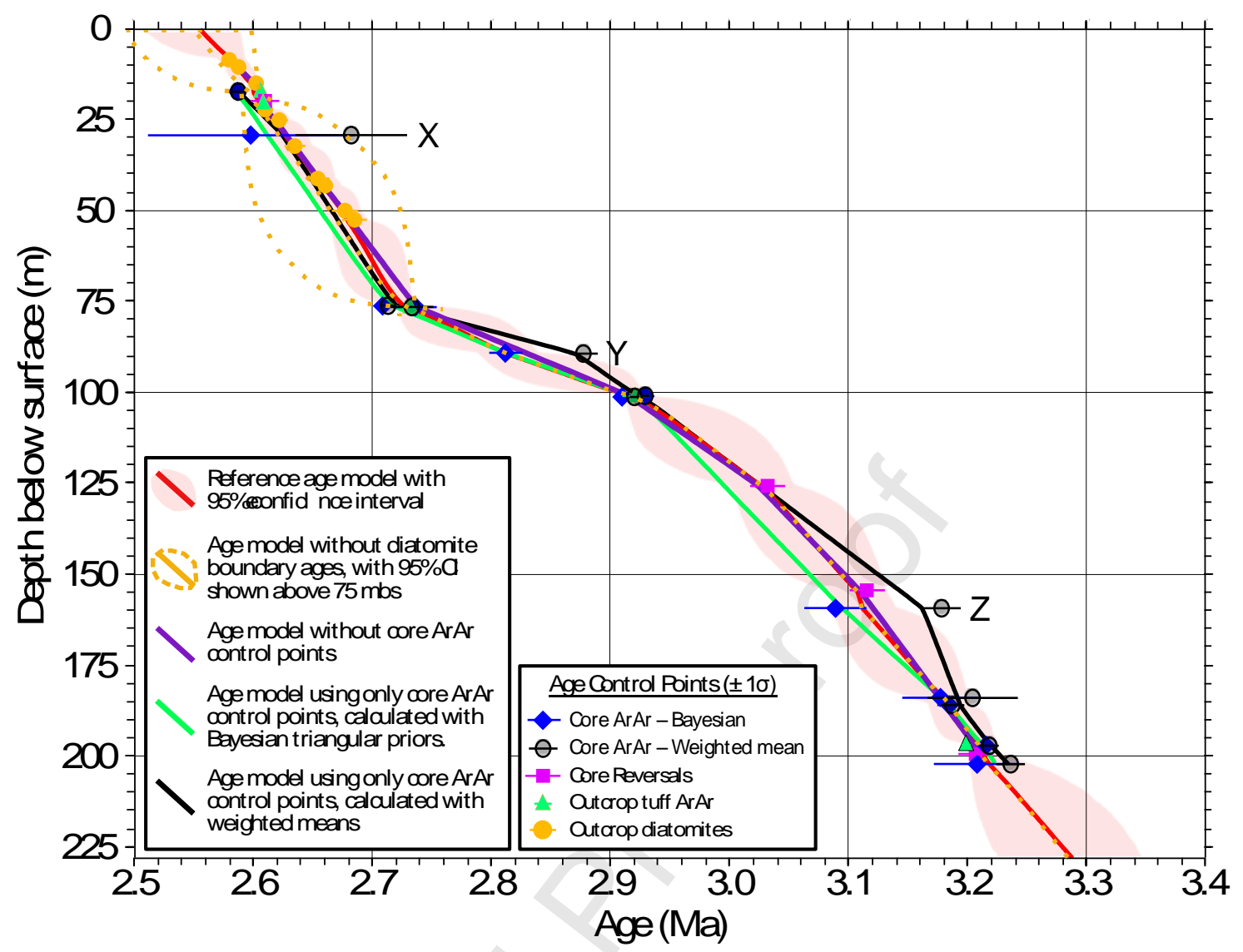

Figure 7. BTB13 Bayesian model comparison and alternative means of deriving a representative age of dated units. The reference model using all available chronostratigraphic control data is shown as the red line with red shading representing a $95 \%$ confidence interval on the age. Three additional models are compared: (1) without the ${ }^{40} \mathrm{Ar} /{ }^{39} \mathrm{Ar}$ control points from the core (purple); (2) using only the ${ }^{40} \mathrm{Ar} /{ }^{39} \mathrm{Ar}$ control points from the core with stratigraphic unit ages derived from the population of single-crystal ages calculated using Bayesian triangular priors (green); and (3) same as (2), except with stratigraphic unit ages calculated using weighted means (black). Three points of maximum departure of the Bayesian and weighted mean unit ages are identified on the plot at points $\mathrm{X}, \mathrm{Y}$, and $\mathrm{Z}$.

\section{Discussion}

\subsection{Prior magmatic and erosional history}

The Tugen Hills have experienced tectonic activity and volcanism associated with rifting since at least the middle Miocene (Chapman and Brook, 1978). The oldest volcanism recorded in the central part of the Tugen Hills are the widespread flood phonolite eruptions 16-13 Ma of the Sidekh and Tiim Phonolites formations 
(Chapman and Brook, 1978; Deino et al., 1990; Jacobs and Deino, 1996; Deino et al., 2002). Voluminous, widespread flows and pyroclastic volcanism (e.g., Ngorora Formation, Ewalel Formation, Kabarnet Trachyte, Kaparaina Basalt) continued throughout the Miocene, ultimately superseded by the predominately fluviolacustrine strata and occasional pyroclastic interbeds of the Chemeron Formation beginning in the latest Pliocene (Deino et al., 2002; Deino and Hill, 2002; Deino et al., 2006).

Xenocrysts in tuff units encountered during single-crystal dating of the BTB13 pyroclastic material, and detrital grains in coarse-grained sandstones examined in the lower portion of the core for their potential geochronological value, provide insight into the volcanotectonic history of the basin. These deposits reveal the age of feldspar-bearing strata that at some earlier stage were eroded and contributed to the sediment load delivered by fluviolacustrine processes to the core site. Figure 8 is an age-probability density plot of single-grain ages from the core dating experiments from $10 \mathrm{Ma}$ to $2.5 \mathrm{Ma}$ (filtered to remove potentially imprecise or altered material); very few single-crystal ages are older than this age range. Although a low level of background activity persists throughout the entire interval, volcanic activity inferred from Figure 8 is concentrated in three main intervals: $\sim 4.1-3.4 \mathrm{Ma}$ (' $\mathrm{A}$ ' and ' $\mathrm{B}$ ' of Figure 8 ), 4.88 Ma (' $\mathrm{C}$ '), and $\sim 8.5-7.4 \mathrm{Ma}$ (' $\mathrm{E}$ '), with a minor episode at 5.81-5.76 Ma (' $\mathrm{D}$ '). The $\sim 4.1-3.4 \mathrm{Ma}$ interval represents by far the most prominent age mode that is older than the base of the core at 3.29 Ma. This mode was likely derived from relatively recently deposited beds of the Chemeron Fm. Erosion of these strata may indicate tectonic disruption of basin geometry and drainage patterns in the $\sim 0.7 \mathrm{Ma}$ prior to the core depositional interval. Unpublished stratigraphic and geochronological work in older, nearby Chemeron Fm. deposits have identified tuffs of the appropriate ages in the Barsemoi and Ndau drainages, within four $\mathrm{km}$ of the core site, with ages in the 3.8-3.6 Ma range. (Deino et al., 2002) note a tuff at Tabarin, $25 \mathrm{~km}$ northwest of the core site, with an age of $3.862 \pm 0.018 \mathrm{Ma}$ that may relate to the peak at $3.88 \mathrm{Ma}$ in the probability age distribution. 


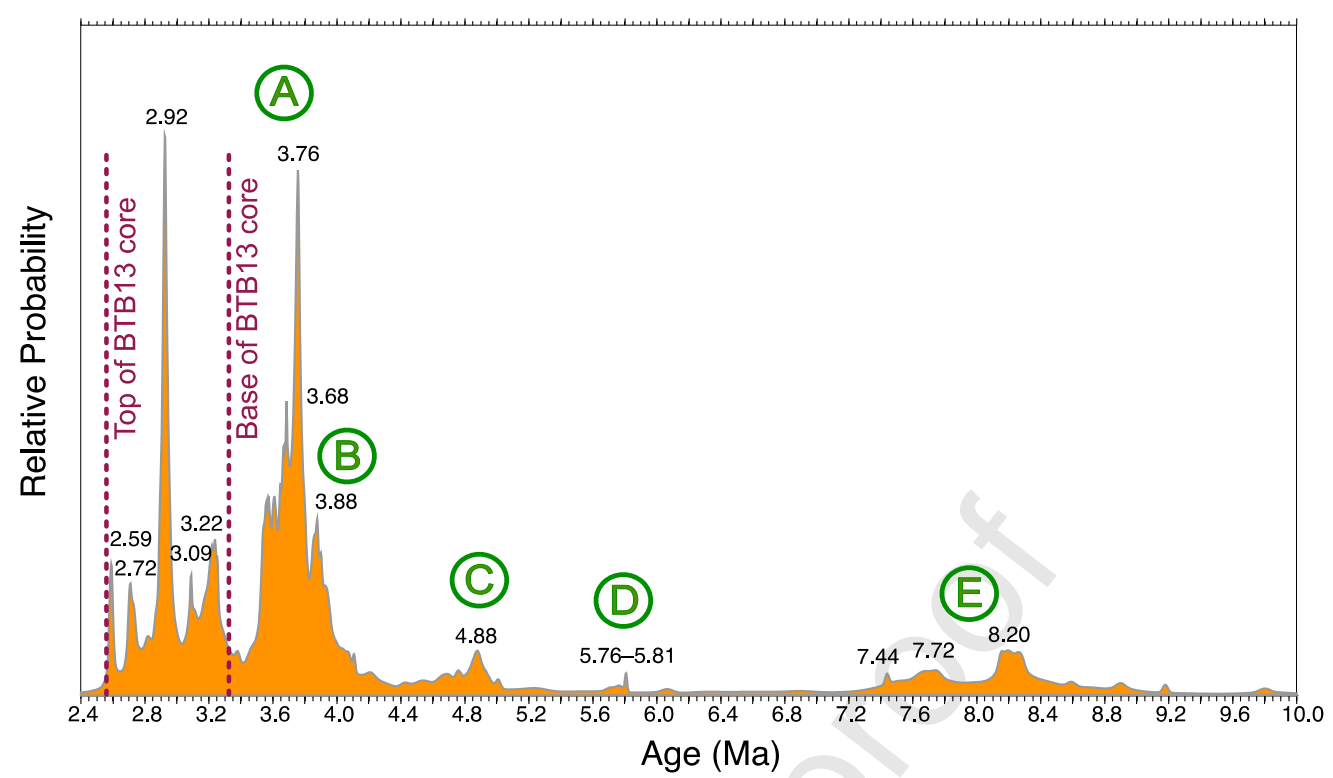

Figure 8. Cumulative age-probability density function of single-grain feldspar ages 10-2.5 Ma. The value of the cumulative density at a given age provides a rough approximation of the relative frequency of the age of feldspar phenocrysts in core dated samples, although distortions occur due to varying numbers of grains analyzed per sample. The original age data set is filtered to avoid altered or imprecise occurrences; the grains represented exhibit $>50 \%{ }^{40} \mathrm{Ar}^{*}$ (radiogenic argon), age $>2.5 \mathrm{Ma}$, and an error in the age $<0.5 \mathrm{Ma} .2,423$ grains are represented, and are derived from the integrated ages of incremental heating experiments, or from single analyses at low temperature where grains were considered too old to complete the incremental heating sequence. Possible outcrop volcanic units are indicated by the circled letter annotations: A. The interval 3.8-3.6 Ma may be represented by several tuffs in the Barsemoi and Ndau river drainages based on unpublished ages; B. 3.88 Ma may be equivalent to tuff sample 94-2 in the Chemeron Fm. at Tabarin $25 \mathrm{~km}$ northwest of the core site, with an age of $3.862 \pm$ $0.018 \mathrm{Ma}$ (Deino et al., 2002); C. 4.88, approximately equivalent to tuff samples 2, 3, and 12 at Tabarin (Deino et al., 2002); D. 5.81-5.76, equivalent in age to tuff samples 18 and 33 in the Lukeino Formation at Tabarin (Deino et al., 2002); E. 8.5-7.4, corresponds broadly to the Ewalel Phonolites and Kabarnet Trachytes (Chapman and Brook, 1978), (Jacobs and Deino, 1996; Deino et al., 2002).

The abundance of grain ages older than $\sim 4.1 \mathrm{Ma}$ is markedly lower than ages of 3.8-3.6 Ma, with lesser peaks at $\sim 4.88 \mathrm{Ma}$ (similar to samples 2, 3, and 12 from the Chemeron Fm., (Deino et al., 2002), and 5.81-5.76 (samples 18 and 33 from the Lukeino Fm., (Deino et al., 2002). The second most prominent broad span of feldspar ages, $\sim 8.5-7.4 \mathrm{Ma}$, correspond generally to the eruptive episodes of the Ewalel Phonolites and Kabarnet Trachytes (Chapman and Brook, 1978; Deino et al., 1990; Jacobs and Deino, 1996; Deino et al., 2002). The oldest grains encountered mostly range up to $14 \mathrm{Ma}$, with one analysis at $25 \mathrm{Ma}$. The middle Miocene activity 
corresponds to the period of emplacement of pyroclastic rocks of the Ngorora Formation and flood lavas of the Tiim Phonolites Formation (Deino et al., 1990).

\subsection{Global climate influences and astronomical forcing}

BTB13 exhibits variations in lithology, facies successions, sediment accumulation rate, zeolite mineralogy, magnetic susceptibility, and gamma density documenting response of the Baringo Basin to cyclical astronomical forcing, on the long eccentricity and precessional time scale, as well as to directional global climate change.

The influence of Earth-orbital eccentricity on climate in the Baringo Basin is demonstrated in BTB13 through features such as major shifts in sedimentation rate, the distribution of lacustrine facies, and zeolite mineralogy. BTB13 $(\sim 3.3-2.5 \mathrm{Ma})$ spans two long-period ( $\sim 405 \mathrm{ka})$ Earth orbital eccentricity cycles (Laskar et al., 2004) (Figure 6.1). An arbitrary threshold of eccentricity ( 0.023; green line) was added to Figure 6.1 to maximize the width of the high and low bands of eccentricity in the interval 3.2-2.5 Ma. This value divides the time interval into two wide bands of high eccentricity from $\sim 3.19-2.92$ and $\sim 2.73-2.55 \mathrm{Ma}$, separated by a low eccentricity band from $\sim 2.92-2.73$ Ma. The earlier high-amplitude eccentricity phase is situated near the bottom of the core ( 3.2-2.9 Ma; 'High Eccentricity Band 1 ' or 'HEB1'), while the second occurs at $\sim 2.7-2.5 \mathrm{Ma}$ ('High Eccentricity Band 2' or 'HEB2'). These are separated by an interval of low eccentricity from $\sim 2.9-2.7 \mathrm{Ma}$.

Several distinct shifts in sediment accumulation rate are evident from the age model, and these coincide with the 405 ka cycle of Earth-orbital eccentricity. Figure 6.4 shows the instantaneous sedimentation rate as a function of age, calculated from the Bayesian age modelling of the core. Mean sedimentation rates are also calculated for four contiguous segments of the model in Figure 6.6. BTB13 is characterized by an early interval of fairly rapid sediment accumulation with peak rates as high as $\sim 80 \mathrm{~cm} / \mathrm{ka}$ and a sustained rate of 32-38 $\mathrm{cm} \mathrm{ka}^{-1}$ from $\sim 200-100$ mbs (3.2-2.92 Ma, G-C). Distinctly slower rates (12 $\left.\mathrm{cm} \mathrm{ka}^{-1}\right)$ occur from 100-76 mbs (2.92 to $2.72 \mathrm{Ma}, \mathrm{C}-\mathrm{B})$, followed abruptly by the fastest sustained rates $\left(49 \mathrm{~cm} \mathrm{ka}^{-1}\right)$ from 76-8.6 mbs (2.72-2.60 Ma, B-A). As shown in Figure 6, there is a high degree of correspondence of the timing of the two rapid zones $(A-B, C-G)$ and intervening zone of slow sediment accumulation (B-C), with intervals of high and low of earth orbital eccentricity, respectively. Although tectonic activity may have led to the changes described above through fluvial erosion, the abruptness of the overall shifts in sedimentation rate, and close coincidence of changes in orbital parameters and sediment accumulation response, suggest that the primary driving mechanism is climate change driven by eccentricity modulation. If so, the depositional setting appears to have responded to lower eccentricity with an increase in fluvial and alluvial environments, as seen in other lake-basins such as the Greater Green River Basin of Eocene Wyoming (Smith et al., 2014).

The occurrence of deep-lake lacustrine facies (thick diatomaceous beds) and high-grade zeolites indicative of high $\mathrm{pH} /$ alkalinity (analcimic mudstones; Minkara et al., this issue), are restricted to zones of BTB13 near the peaks of HEB2. As discussed below, the deep-lake facies alternate with episodes of high alkalinity at a 
precessional scale, but it is high eccentricity that modulates the precessional insolation swings to maximum levels (Figure 6.2). It should be noted that the deep lake facies are limited to two main stratigraphic intervals during HEB1, but occur over multiple successive cycles in HEB2. The tempered response in HEB1 to an even higher degree of eccentricity than in HEB2 may be a function of global climate conditions, as discussed below, or related to basin evolution.

Several sedimentological aspects of BTB13 document precessional paced cyclical variation in paleoenvironments, including the development of deep-lake diatomaceous facies (Westover et al., this issue), the distribution and composition of zeolite mineral suites (Minkara et al., this issue), and the cyclical nature of facies successions. These variations are especially prominent during periods of high eccentricity.

A series of five diatomaceous units (D1-D5) near the top of the core exhibit precessional pacing and are approximately coincident with insolation maxima, and several diatomaceous units (including D0) in the middle portion of the core also coincide with an insolation maximum (Figure 6.2; Deino et al., 2006; Kingston et al., 2007; Westover et al., this issue). Note that the insolation model is calculated for $30^{\circ} \mathrm{N}$ latitude on June 21 (Laskar et al., 2004). These parameters follow the conclusion of (Deino et al., 2006) regarding the Chemeron outcrop succession, which noted that the timing of the lacustrine pulses relative to insolation variation favored origination of moisture from the northern Africa monsoon (boreal summer), rather than local circulation driven by direct equatorial insolation (e.g., long rains in March at equatorial latitude). The insolation curve would shift about a quarter of a precessional cycle older were the latter parameters chosen, although the frequency would be preserved.

Both outcrop and core exhibit a single prominent diatomite (D0) below the D1-D5 package, toward the middle of the core at a model age of 3.04 Ma (Figure 6). Previously, the age of this diatomite was only estimated through extrapolation from dated tephra higher in the section as observed in outcrop (Deino et al., 2006). The core model provides confirmation that this diatomite is situated near the eccentricity maximum of HEB1, coincident with its most extreme insolation peak.

Minkara et al. (this issue) have analyzed the authigenic silicates in BTB13, which help to confirm the precessional pace of climate change in HEB2 identified through the occurrence of diatomites (herein and Deino et al., 2006), and add that the freshwater diatomites associated with insolation maxima are intercalated with analcime-cemented sediments. The zeolite mineralogy reflects the conditions and processes operating in lacustrine and lake-margin environments. The timing of these zeolitic mineral suites in BTB13 can be used to help interpret the effect of climate on Baringo Basin paleoenvironments. The alternation between diatoms and the high $\mathrm{pH} /$ high salinity zeolites (i.e., analcime), and their association with particular sedimentary facies in BTB13, together indicate that climate fluctuations, modulated by high eccentricity, operated on the precession scale (Minkara et al., this issue). Notably, during HEB2, the especially thick diatomite and diatomaceous units between $\sim 2.7 \mathrm{Ma}$ and 2.6 Ma represent the freshest lacustrine intervals within the core (Westover et al., this issue), at a time when the intercalated zeolitic sediments indicate the most saline and alkaline intervals. These extreme fluctuations in 
conditions within the Baringo Basin are most evident during peak orbital eccentricity (Minkara et al., this issue).

Sequence stratigraphic boundaries identified in BTB13 document the sedimentological response of the Baringo Basin to precession-scale insolation variation (Figure 6.3; Table S8) (Scott et al., this issue). The stratigraphic sequences, interpreted from the packaging of sedimentary facies, are bounded by sequence boundaries that represent discontinuities (i.e., exposure surfaces) or the most landward facies in a succession. Sequence boundaries are nearly coincident with insolation maxima in the first half of HEB1, and throughout most of HEB2, with a few tentative matches to low intensity insolation peaks in the LEB (Figure 6.3). Interpretation of the temporal relationship of sequence boundaries to insolation in the upper part of HEB1 is complicated due to possible presence of a fault and an unconformity in this interval. Overall, model ages for sequence boundaries lead insolation peaks by 2 ka (Table S8). This small divergence between the sequence boundaries and calculated insolation for $30^{\circ} \mathrm{N}$, June (Laskar et al., 2004), and an absence of a consistent trend in the divergence, suggests that: (1) the model insolation curve is appropriate for the Baringo Basin during the studied time interval; and, (2) sequence boundaries coincide with maxima in precessionally forced insolation. Potentially three intervals of sequence boundaries are evidenced: obliquity (six boundaries at a median spacing of $40 \mathrm{ka}$ ), precession (13 at a median spacing of $21 \mathrm{ka}$ ), and half-precession (three cycles with a $13 \mathrm{ka}$ spacing).

The BTB13 interval encompasses several major shifts in global climate patterns that are at the crux of worldwide climate change in the Plio-Pleistocene, evidenced in the oxygen isotope variations in deep marine core records (Figure 6.5; Lisiecki and Raymo, 2005). The core interval begins with the mid-Piacenzian warm period (MPWP), a relatively short duration global event (3.27-2.97 Ma) that is approximately coincident with HEB1. The MPWP is followed by a progressively intensifying global cooling trend continuing into the Holocene, initially reflected by an increase of southern hemisphere ice volume, but by $2.7 \mathrm{Ma}$ linked also to the dramatic growth of northern hemisphere glaciers (De Schepper et al., 2014).

BTB13 appears to record the influence of the MPWP and the progressive deterioration of global climate that followed it. These global warming and cooling trends may be revealed in BTB13 by the differences in sedimentation rate and paleoenvironments exhibited during eccentricity maxima HEB1 and HEB2. BTB13 chronicles high-amplitude precessionally paced climate oscillations in HEB2, resulting in multiple successive cycles of diatomaceous deep lake sediments alternating with alkaline lake conditions. During the HEB1 within the MPWP, in contrast, alternating wet-dry cycles are less pronounced and produce the occurrence of freshwater diatomite (D0), along with a subsequent diatomaceous interval (Westover et al., this issue; Minkara et al., this issue; Scott et al., this issue). Three older lacustrine stratigraphic units, interpreted to represent a smaller, and probably saline and alkaline lake, also correspond well to precession in the initial period of HEB1 (Scott et al., this issue). The differing response at the maximum of Earth-orbital eccentricity may be related to warmer conditions during HEB1 and distinctly cooler conditions by HEB2, although the driving mechanisms remain obscure. 
Minkara et al. (Minkara et al., this issue) observe, through analysis of authigenic silicates in BTB13, that a significant change occurred at about $2.98 \mathrm{Ma}$ [near the end of the MPWP], when the lacustrine system transitioned from purely phillipsite production to a diversity of alkaline zeolites, depending on climatic conditions. The upper part of the core is represented by more sodic zeolites (analcime), rather than calcic or potassic zeolites, suggesting a long-term trend in aridity and concentration of sodium in the lake basin.

Trends in continuous core logging parameters such as magnetic susceptibility and gamma density may also document the end of the MPWP and subsequent global cooling (Figure 6). Notably, the gamma density and magnetic susceptibility records from BTB13 indicate a dramatic change in character at $\sim 3 \mathrm{Ma}$ (c. D0), from low-amplitude, high frequency oscillations at the base, to higher amplitude, lower frequency oscillations that intensify upward in the core (Figure 6.8; Cohen et al., 2016). The influence of these longer-term trends on accumulated sediments in BTB13 appears to be independent of Earth-orbital eccentricity at both the 100- and 400-thousand-year scales.

\section{Conclusions}

A total of 32 control points are used to develop a Bayesian chronostratigraphic model for the Baringo-Tugen Hills-Barsemoi core from the Tugen Hills, Kenya (BTB13). The age model reveals three main intervals of sedimentation inferred from rates of accumulation: (1) an early rapid phase from 3.2-2.9 Ma; (2) a relatively slow phase from 2.9-2.7 Ma; and (3) the highest rate of accumulation from 2.7-2.6 Ma. The intervals of rapid accumulation correspond to periods of high earth orbital eccentricity, while the slow accumulation interval corresponds closely to the interval of low eccentricity at 2.9-2.7 Ma. This correspondence suggests that orbitally mediated climate processes may be ultimately responsible for changes in sediment accumulation rate in the basin during this interval, rather than tectonic driving forces.

BTB13 may be unique as a continental equatorial sedimentary record encompassing the critical climate interval from the mid-Piacenzian warm period (3.27-2.97 Ma), the initiation of global cooling at $\sim 3.0 \mathrm{Ma}$, and the initiation and intensification of Northern Hemispheric glaciation beginning 2.7 Ma (De Schepper et al., 2014). These major shifts in global climate patterns may manifest in equatorial East Africa in the Baringo Basin as changes in sedimentary successions and authigenic mineralogy at $\sim 2.9 \mathrm{Ma}$. The change is clearly demonstrated in gamma density and magnetic susceptibility core logs, from low-amplitude, high frequency oscillations at the base, into higher amplitude, lower frequency oscillations intensifying upward to the top of the core. These data may represent the first direct evidence of a global connection between the intensification of glaciation at high latitudes and continental equatorial climate near the end of the Pliocene.

BTB13 demonstrates two intervals with paleoenvironments strongly influenced by orbital precession cyclicity. Almost all of the sequence stratigraphic boundaries, interpreted from the packaging of sedimentary facies in the core, align with insolation maxima, and are most prominent during times of high eccentricity 
when the dynamic shifts in insolation reach their maximum amplitude. Additionally, the thick diatom-dominated deep-lake deposits are temporally aligned with insolation maxima at $\sim 3.04$ and $\sim 2.68-2.58$ Ma.

\section{Acknowledgments}

We wish to acknowledge our gratitude to our late colleague, Dr. Andrew Hill, whose career-long dedication to the geology and paleontology of the Baringo Basin fired our own interest in this fascinating and complex area. We are grateful for discussions and ongoing contributions by our colleagues of the Baringo-Tugen HillsBarsemoi (BTB), Baringo Paleontology Research Project (BPRP), and Hominin Sites and Paleolakes Drilling Project (HSPDP) research groups. This project was supported by the International Continental Drilling Program (ICDP) and the National Science Foundation [grants EAR 1123942, BCS 1241790, EAR 1338553, and EAR 1322017] and a Natural Sciences and Engineering Research Council (NSERC) of Canada DDG grant to JJS. Research and drilling permits were provided by the Kenyan National Council for Science and Technology, the Kenyan Ministry of Mines and the National Environmental Management Authority of Kenya and facilitated by the National Museums of Kenya. We thank DOSECC Exploration Services for drilling supervision, Drilling and Prospecting International (DPI) for drilling services and the US National Lacustrine Core Facility for core handling, processing and storage facilities.

\section{Supplemental Tables}

Table S1. ${ }^{40} \mathrm{Ar} /{ }^{39} \mathrm{Ar}$ analytical data

Table S2. ${ }^{40} \mathrm{Ar} /{ }^{39} \mathrm{Ar}$ single-grain incremental heating results

Table S3. ${ }^{40} \mathrm{Ar} /{ }^{39} \mathrm{Ar}$ control points for Bayesian model of outcrop section

Table S4. Bayesian age model for outcrop diatomaceous section

Table S5. BTB13 Bayesian age model

Table S6. BTB13 age model trial variations

Table S7. Comparison of ${ }^{40} \mathrm{Ar} /{ }^{39} \mathrm{Ar}$ calculation methods

Table S8. Position and timing of sequence boundaries

\section{Supplemental Figure}

Figure S1. Probability-density plots of individual tuff units showing the cumulative gaussian population characteristics of single-crystal plateau ages. Open/red symbols represent analyses omitted from the inferred primary eruptive population. Weighted-mean ages and $1 \sigma$ analytical uncertainty (including error in $J$, the neutron fluence parameter) are shown toward the middle-left of each plot.

\section{References}

Bishop, W.W., Chapman, G.R., Hill, A., and Miller, J.A., 1971. Succession of Cainozoic vertebrate assemblages from the northern Kenya Rift Valley. Nature 233389- 
233394.

Blegen, N., 2017. The earliest long-distance obsidian transport: Evidence from the similar to 200 ka Middle Stone Age Sibilo School Road Site, Baringo, Kenya. J. Hum. Evol. 1031-1019.

Bromley, R.G., and Ekdale, A.A., 1986. Composite ichnofabrics and tiering of burrows. Geological Magazine 12359-12365.

Campisano, C.J., Cohen, A.S., Arrowsmith, J.R., Asrat, A., Behrensmeyer, A.K., Brown, E.T., Deino, A.L., Deocampo, D.M., Feibel, C.S., Kingston, J.D., Lamb, H.F., Lowenstein, T.K., Noren, A., Olago, D.O., Owen, R.B., Pelletier, J.D., Potts, R., Reed, K.E., Renaut, R.W., Russell, J.M., Russell, J.R., Schäbitz, F., Stone, J.R., Trauth, M.H., and Wynn, J.G., 2017. The Hominin Sites and Paleolakes Drilling Project: Acquiring High-Resolution Paleoclimate Records from the East African Rift System and Their Implications for Understanding the Environmental Context of Hominin Evolution. Paleoanthropology 1-43.

Chapman, G., and Brook, M., 1978. Chronostratigraphy of the Baringo Basin, Kenya. Geological Society of London Special publication 6(1) 207 -223.

Chapman, G.R., Lippard, S.J., and Martyn, J.E., 1978. The stratigraphy and structure of the Kamasia Range, Kenya Rift Valley. Jl geol. Soc. Lond. 135265-135281.

Cohen, A., Campisano, C., Arrowsmith, R., Asrat, A., Behrensmeyer, A.K., Deino, A., Feibel, C., Hill, A., Johnson, R., Kingston, J., Lamb, H., Lowenstein, T., Noren, A., Olago, D., Owen, R.B., Potts, R., Reed, K., Renaut, R., Schaebitz, F., Tiercelin, J.J., Trauth, M.H., Wynn, J., Ivory, S., Brady, K., O’Grady, R., Rodysill, J., Githiri, J., Russell, J., Foerster, V., Dommain, R., Rucina, S., Deocampo, D., Russell, J., Billingsley, A., Beck, C., Dorenbeck, G., Dullo, L., Feary, D., Garello, D., Gromig, R., Johnson, T., Junginger, A., Karanja, M., Kimburi, E., Mbuthia, A., McCartney, T., McNulty, E., Muiruri, V., Nambiro, E., Negash, E.W., Njagi, D., Wilson, J.N., Rabideaux, N., Raub, T., Sier, M.J., Smith, P., Urban, J., Warren, M., Yadeta, M., Yost, C., and Zinaye, B., 2016. The Hominin Sites and Paleolakes Drilling Project: inferring the environmental context of human evolution from eastern African rift lake deposits. Sci. Drill. 211-216.

De Schepper, S., Gibbard, P.L., Salzmann, U., and Ehlers, J., 2014. A global synthesis of the marine and terrestrial evidence for glaciation during the Pliocene Epoch. EarthScience Reviews 13583-13102.

Deino, A., Tauxe, L., Monaghan, M., and Drake, R., 1990. Ar-40/Ar-39 age calibration of the lithomagnetic and paleomagnetic stratigraphies of the Ngorora Formation, Kenya. J. Geol. 98(4) 567-587.

Deino, A.L., and Hill, A., 2002. Ar-40/Ar-39 dating of Chemeron Formation strata encompassing the site of hominid KNM-BC 1, Tugen Hills, Kenya. J. Hum. Evol. 42(1-2) 141-151.

Deino, A.L., and McBrearty, S., 2002. Ar-40/Ar-39 dating of the Kapthurin Formation, Baringo, Kenya. J. Hum. Evol. 42(1-2) 185-210.

Deino, A.L., Kingston, J.D., Glen, J.M., Edgar, R.K., and Hill, A., 2006. Precessional forcing of lacustrine sedimentation in the late Cenozoic Chemeron Basin, Central Kenya Rift, and calibration of the Gauss/Matuyama boundary. Earth Planet. Sci. Lett. 247(1-2) 41-60.

Deino, A.L., Tauxe, L., Monaghan, M., and Hill, A., 2002. Ar-40/Ar-30 geochronology 
and paleomagnetic stratigraphy of the Lukeino and lower Chemeron Formations at Tabarin and Kapcheberek, Tugen Hills, Kenya. J. Hum. Evol. 42(1-2) 117-140.

Fleck, R.J., Sutter, J.F., and Elliot, D.H., 1977. Interpretation of discordant ${ }^{40} \mathrm{Ar} /{ }^{39} \mathrm{Ar}$ agespectra of Mesozoic tholeiites from Antarctica. Geochimica et Cosmochimica Acta 4115-4132.

Garello, D.I., 2019. Tephrostratigraphy of Pliocene Drill Cores from Kenya and Ethiopia, and Pleistocene Exposures in the Ledi-Geraru Research Project Area, Ethiopia: Geological Context for the Evolution of Australopithecus and Homo. PhD thesis, Arizona State University, $597 \mathrm{pp}$.

Garello, D.I., Deino, A.L., Campisano, C.K., Kingston, J.D., this issue. Geochemical characterization of tephra from the upper Chemeron Formation (3.3-2.6 Ma), Baringo Basin, Kenya, and correlations between outcrop and the Baringo-Tugen Hills-Barsemoi drill core. In Scott, J.J., Stone, J.R., Sier, M.J., Kingston, J.D. (eds.), A high-resolution, multi-proxy record of Pliocene hominin environments in the Kenya Rift Valley: Analysis of the Baringo-Tugen Hills-Barsemoi (BTB) Drill Core. Palaeogeography, Palaeoclimatology, Palaeoecology.

Gelman, A., Carlin, J.B., Stern, H.S., Dunson, D.B., Vehtari, A., and Rubin, D.B., 2013. Bayesian Data Analysis. Taylor \& Francis Group / CRC Press.

Hagstrum, J.T., Fleck, R.J., Evarts, R.C., and Calvert, A.T., 2017. Paleomagnetism and Ar-40/Ar-39 geochronology of the Plio-Pleistocene Boring Volcanic Field: Implications for the geomagnetic polarity time scale and paleosecular variation. Phys. Earth Planet. Inter. 262101-262115.

Harmand, S., Lewis, J.E., Feibel, C.S., Lepre, C.J., Prat, S., Lenoble, A., Boes, X., Quinn, R.L., Brenet, M., Arroyo, A., Taylor, N., Clement, S., Daver, G., Brugal, J.-P., Leakey, L., Mortlock, R.A., Wright, J.D., Lokorodi, S., Kirwa, C., Kent, D.V., and Roche, H., 2015. 3.3-million-year-old stone tools from Lomekwi 3, West Turkana, Kenya. Nature 521(7552) 310.

Hill, A., 1985. Early hominid from Baringo, Kenya. Nature 315(6016) 222-224.

Hill, A., 1994. Late Miocene and Early Pliocne hominoids from Africa. in: Corruccini, R.S., and Ciochon, R.L., (eds.), Integrative paths to the past. Prentice Hall, Englewood Cliffs, New Jersey, pp. 123-145.

Hill, A., and Ward, S., 1988. Origin of the hominidae - the record of African large hominoid evolution between 14-my and 4-my. Yearb. Phys. Anthropol. 3149-3183.

Hill, A., Curtis, G., and Drake, R., 1986. Sedimentary stratigraphy of the Tugen Hills. in: Frostick, L.E., Renaut, R.W., Reid, I., and Tiercelin, J.J., (eds.), Sedimentation in the African Rifts. Geol. Soc. London, pp. 285-295.

Hill, A., Drake, R., Tauxe, L., Monaghan, M., Barry, J.C., Behrensmeyer, A.K., Curtis, G., Jacobs, B.F., Jacobs, L., Johnson, N., and Pilbeam, D., 1985. Neogene palaeontology and geochronology of the Baringo basin, Kenya. Journal of Human Evolution 14759-14773.

Hill, A., Ward, S., Deino, A., Curtis, G., and Drake, R., 1992. Earliest Homo. Nature 355(6362) 719-722.

Jacobs, B.F., and Deino, A.L., 1996. Test of climate-leaf physiognomy regression models, their application to two Miocene floras from Kenya, and Ar-40/Ar-39 dating of the late Miocene Kapturo site. Paleogeogr. Paleoclimatol. Paleoecol. 123(1-4) 259-271. 
Keller, C.B., Schoen, B., and Samperton, K.M., 2018. A stochastic sampling approach to zircon eruption age interpretation. Geochemical Perspectives Letters 831-835.

Kingston, J.D., Deino, A.L., Edgar, R.K., and Hill, A., 2007. Astronomically forced climate change in the Kenyan Rift Valley 2.7-2.55 Ma: implications for the evolution of early hominin ecosystems. J. Hum. Evol. 53(5) 487-503.

Koymans, M.R., Langereis, C.G., Pastor-Galan, D., and van Hinsbergen, D.J.J., 2016. Paleomagnetism.org: An online multi-platform open source environment for paleomagnetic data analysis. Comput. Geosci. 93127-93137.

Kuehn, S.C., Froese, D.G., Shane, P.A.R., and INTAV, I.P., 2011. The INTAV intercomparison of electron-beam microanalysis of glass by tephrochronology laboratories: Results and recommendations. Quat. Int. 24619-24647.

Kuiper, K.F., Deino, A., Hilgen, F.J., Krijgsman, W., Renne, P.R., and Wijbrans, J.R., 2008. Synchronizing rock clocks of Earth history. Science 320(5875) 500-504.

Lane, C., Haslam, M., Petraglia, M., Ditchfield, P., Smith, V., and Korisettar, R., 2011. Cryptotephra from the 74 ka BP Toba super-eruption in the Billa Surgam caves, southern India. Quat. Sci. Rev. 30(15-16) 1819-1824.

Lane, C.S., Chorn, B.T., and Johnson, T.C., 2013. Ash from the Toba supereruption in Lake Malawi shows no volcanic winter in East Africa at 75 ka. Proc. Natl. Acad. Sci. U. S. A. 110(20) 8025-8029.

Laskar, J., Robutel, P., Joutel, F., Gastineau, M., Correia, A., and Levard, B., 2004. A long-term numerical solution for the insolation quantities of the earth. Astron. Astrophys 428261-428285.

Lee, J.-Y., Marti, K., Severinghaus, J.P., Kawamura, K., Yoo, H.-S., Lee, J.B., and Kim, J.S., 2006. A redetermination of the isotopic abundances of atmospheric Ar. Geochimica et Cosmochimica Acta 704507-704512.

Lisiecki, L.E., and Raymo, M.E., 2005. A Pliocene-Pleistocene stack of 57 globally distributed benthic delta O-18 records. Paleoceanography 20(2)

Lockwood, C.A., Kimbel, W.H., and Johanson, D.C., 2000. Temporal trends and metric variation in the mandibles and dentition of Australopithecus afarensis. J. Hum. Evol. 39(1) 23-55.

Lowe, D.J., 2011. Tephrochronology and its application: A review. Quat. Geochronol. 6(2) 107-153.

McCall, G.J.H., Baker, B.H., and Walsh, J., 1967. Late Tertiary and Quaternary sediments of the Kenya Rift Valley. in: Bishop, W.W., and Clark, J.D., (eds.), Background to Evolution in Africa. Chicago University, Chicago, pp. 191-220.

McPherron, S.P., Alemseged, Z., Marean, C.W., Wynn, J.G., Reed, D., Geraads, D., Bobe, R., and Bearat, H.A., 2010. Evidence for stone-tool-assisted consumption of animal tissues before 3.39 million years ago at Dikika, Ethiopia. Nature 466857466860.

Min, K.W., Mundil, R., Renne, P.R., and Ludwig, K.R., 2000. A test for systematic errors in Ar-40/Ar-39 geochronology through comparison with $\mathrm{U} / \mathrm{Pb}$ analysis of a 1.1-Ga rhyolite. Geochim. Cosmochim. Acta 64(1) 73-98.

Minkara, K.E., Deocampo, D.M., Rabideaux, N.M., Kingston, J.D., Deino, A.L., Cohen, A.S., Campisano, C.J., this issue. Zeolite facies and implications for environmental change from the Chemeron Formation of the Baringo Basin, Kenya Rift, 3.3-2.6 Ma. In Scott, J.J., Stone, J.R., Sier, M.J., Kingston, J.D. (eds.), A high-resolution, 
multi-proxy record of Pliocene hominin environments in the Kenya Rift Valley: Analysis of the Baringo-Tugen Hills-Barsemoi (BTB) Drill Core. Palaeogeography, Palaeoclimatology, Palaeoecology.

Niespolo, E.M., Rutte, D., Deino, A.L., and Renne, P.R., 2017. Intercalibration and age of the Alder Creek sanidine Ar-40/Ar-39 standard. Quat. Geochronol. 3920539213.

Ogg, J.G., Gradstein, F.M., Ogg, J.G., Schmitz, M.D., and Ogg, G.M., 2012. Geomagnetic Polarity Time Scale. 85-113.

Pearce, N.J.G., Perkins, W.T., Westgate, J.A., and Wade, S.C., 2012. Trace-element microanalysis by LA-ICP-MS: The quest for comprehensive chemical characterisation of single, sub-10 mu m volcanic glass shards. Quat. Int. 276298276298.

Reed, K.E., and Rector, A.L., 2007. African Pliocene paleoecology: Hominin habitats, resources, and diets. in: Ungar, P.S., (ed.), Evolution of the Human Diet: The Known, the Unknown, and the Unknowable. pp. 262-288.

Scott, J.J., Chupik, D.T., Deino, A.L., Stockhecke, M., Kingston, J.D., Westover, K.S., Lukens, W.E., Deocampo, D.M., Yost, C.L., Billingsley, A.L., Minkara, K.E., Ortiz, K., Cohen, A.S., this issue. Sequence stratigraphic framework for lacustrine transgression-regression cycles in the 3.3-2.6 Ma interval of the Chemeron Formation BTB13 core, Baringo Basin, Kenya Rift Valley. In Scott, J.J., Stone, J.R., Sier, M.J., Kingston, J.D. (eds.), A high-resolution, multi-proxy record of Pliocene hominin environments in the Kenya Rift Valley: Analysis of the BaringoTugen Hills-Barsemoi (BTB) Drill Core. Palaeogeography, Palaeoclimatology, Palaeoecology.

Senut, B., Pickford, M., Gommery, D., Mein, P., Cheboi, K., and Coppens, Y., 2001. First hominid from the Miocene (Lukeino Formation, Kenya). Comptes Rendus Acad. Sci. Ser II-A 332(2) 137-144.

Sier, M.J., Langereis, C.G., Dupont-Nivet, G., Feibel, C.S., Joordens, J.C.A., van der Lubbe, J.F., Beck, C.C., Olago, D., Cohen, A., and WTK, S.T.M., 2017. The top of the Olduvai Subchron in a high-resolution magnetostratigraphy from the West Turkana core WTK13, hominin sites and Paleolakes Drilling Project (HSPDP). Quat. Geochronol. 42117-42129.

Sier, M.J., Dupont-Nivet, G., Langereis, C., Deino, A.L., Kingston, J.D., Cohen, A.S., this issue. Magnetostratigraphy of the Hominin Sites and Paleolakes Drilling Project (HSPDP) Baringo-Tugen Hills-Barsemoi core (Kenya). In Scott, J.J., Stone, J.R., Sier, M.J., Kingston, J.D. (eds.), A high-resolution, multi-proxy record of Pliocene hominin environments in the Kenya Rift Valley: Analysis of the BaringoTugen Hills-Barsemoi (BTB) Drill Core. Palaeogeography, Palaeoclimatology, Palaeoecology.

Smith, M.E., Carroll, A.R., Scott, J.J., and Singer, B.S., 2014. Early Eocene carbon isotope excursions and landscape destabilization at eccentricity minima: Green River Formation of Wyoming. Earth and Planetary Science Letters 403393-403406. Villmoare, B., Kimbel, W.H., Seyoum, C., Campisano, C.J., DiMaggio, E.N., Rowan, J., Braun, D.R., Arrowsmith, J.R., and Reed, K.E., 2015. Early Homo at 2.8 Ma from Ledi-Geraru, Afar, Ethiopia. Science 347(6228) 1352-1355.

Westover, K.S., Stone, J.R., Yost, C.L., Scott, J.J., Cohen, A.S., Rabideaux, N.M., 
Stockhecke, M., Kingston, J.D., this issue. Diatom paleolimnology of late Pliocene Baringo Basin (Kenya) paleolakes. In Scott, J.J., Stone, J.R., Sier, M.J., Kingston, J.D. (eds.), A high-resolution, multi-proxy record of Pliocene hominin environments in the Kenya Rift Valley: Analysis of the Baringo-Tugen HillsBarsemoi (BTB) Drill Core. Palaeogeography, Palaeoclimatology, Palaeoecology. White, T.D., Asfaw, B., Beyene, Y., Haile-Selassie, Y., Lovejoy, C.O., Suwa, G., and WoldeGabriel, G., 2009. Ardipithecus ramidus and the Paleobiology of Early Hominids. Science 326(5949) 75-86. 